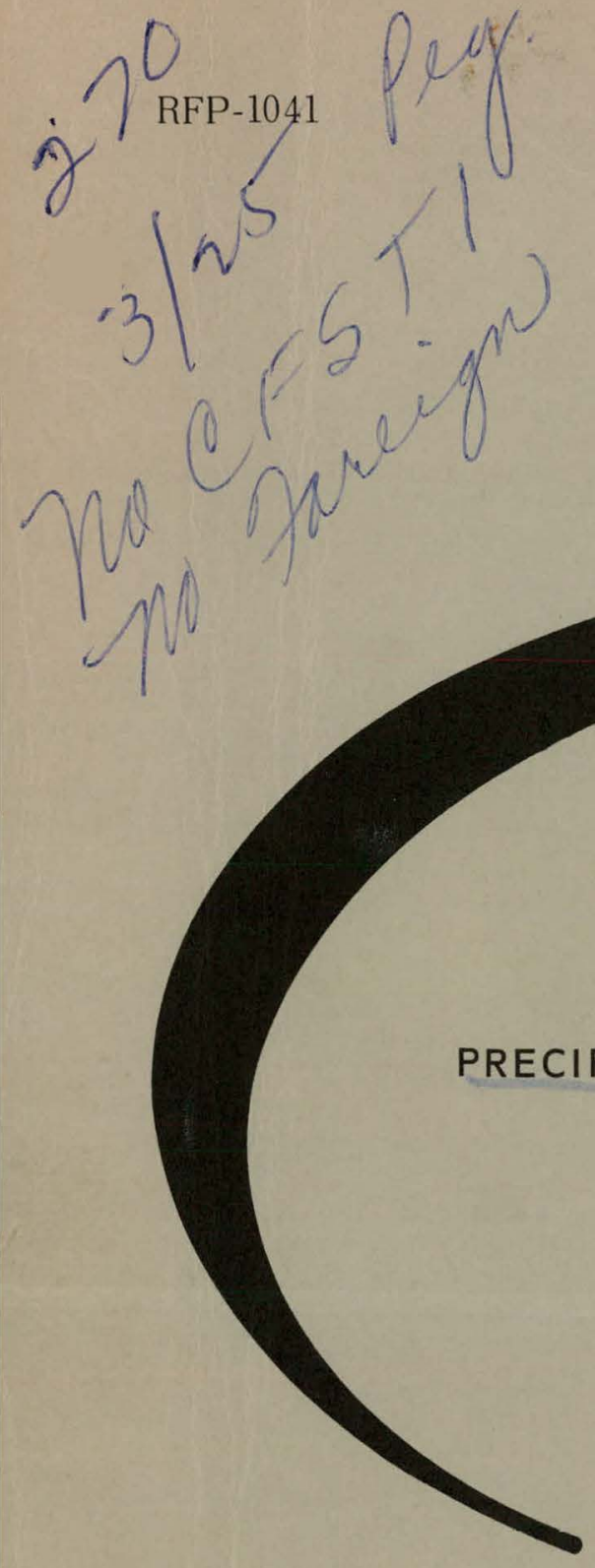

1. This report is subject to Department of Commerce Comprehensive Export Schedule Part 385.2(c)(3)(v).

2. This report may not be published in whole or in part without approval of the Atomic Energy Commission.

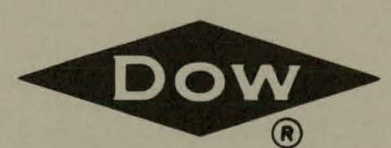
THE DOW CHEMICAL COMPANY ROCKY FLATS DIVISION
P. O. BOX 888
GOLDEN, COLORADO 80401
U.S. ATOMIC ENERGY COMMISSION
CONTRACT AT(29-1)-1106




\section{DISCLAIMER}

This report was prepared as an account of work sponsored by an agency of the United States Government. Neither the United States Government nor any agency Thereof, nor any of their employees, makes any warranty, express or implied, or assumes any legal liability or responsibility for the accuracy, completeness, or usefulness of any information, apparatus, product, or process disclosed, or represents that its use would not infringe privately owned rights. Reference herein to any specific commercial product, process, or service by trade name, trademark, manufacturer, or otherwise does not necessarily constitute or imply its endorsement, recommendation, or favoring by the United States Government or any agency thereof. The views and opinions of authors expressed herein do not necessarily state or reflect those of the United States Government or any agency thereof. 


\section{DISCLAIMER}

Portions of this document may be illegible in electronic image products. Images are produced from the best available original document. 


\section{LEGAL NOTICE}

This report was prepared as an account of Government sponsored work. Neither the United States, nor the Commission, nor any person acting on behalf of the Commission:

A. Makes any warranty or representation, expressed or implied, with respect to the accuracy, completeness, or usefulness of the information contained in this report, or that the use of any information, apparatus, method, or process disclosed in this report may not infringe privately owned rights; or

B. Assumes any liabilities with respect to the use of, or for damages resulting from the use of any information, apparatus, method, or process disclosed in this report.

As used in the above, "person acting on behalf of the Commission" includes any employee or contractor of the Commission, or employee of such contractor, to the extent that such employee or contractor of the Commission, or employee of such contractor prepares, disseminatęs, or provides access to, any information pursuant to his employment or contract with the Commission, or his employment with such contractor. 


\title{
PRECIPITATION CHARACTERISTICS OF ROCKY FLATS BERYLLIUM INGOT SHEET
}

\author{
Frederick J. Fraikor \\ Virgil K. Grotzky \\ Arvel W. Brewer \\ Howard E. Reed
}

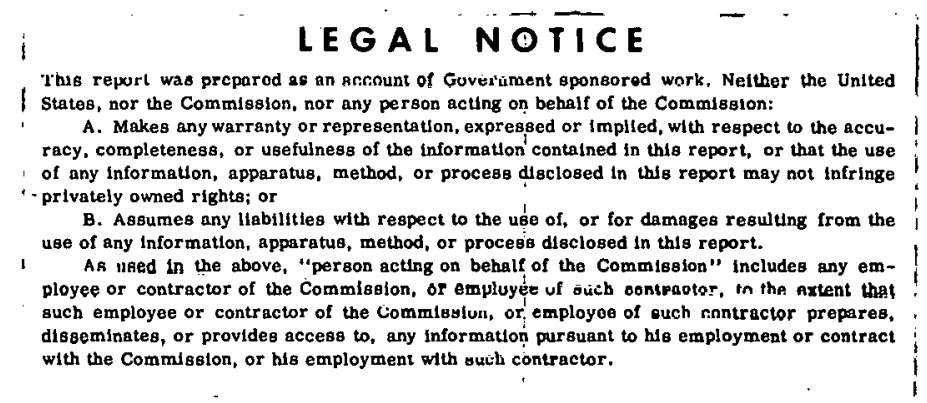

\author{
THE DOW CHEMICAL COMPANY \\ ROCKY FLATS DIVISION \\ P. O. BOX 888 \\ GOLDEN, COLORADO 80401 \\ U. S. ATOMIC ENERGY COMMISSION \\ CONTRACT AT(29-1)-1106
}


RFP-1041 


\section{CONTENTS}

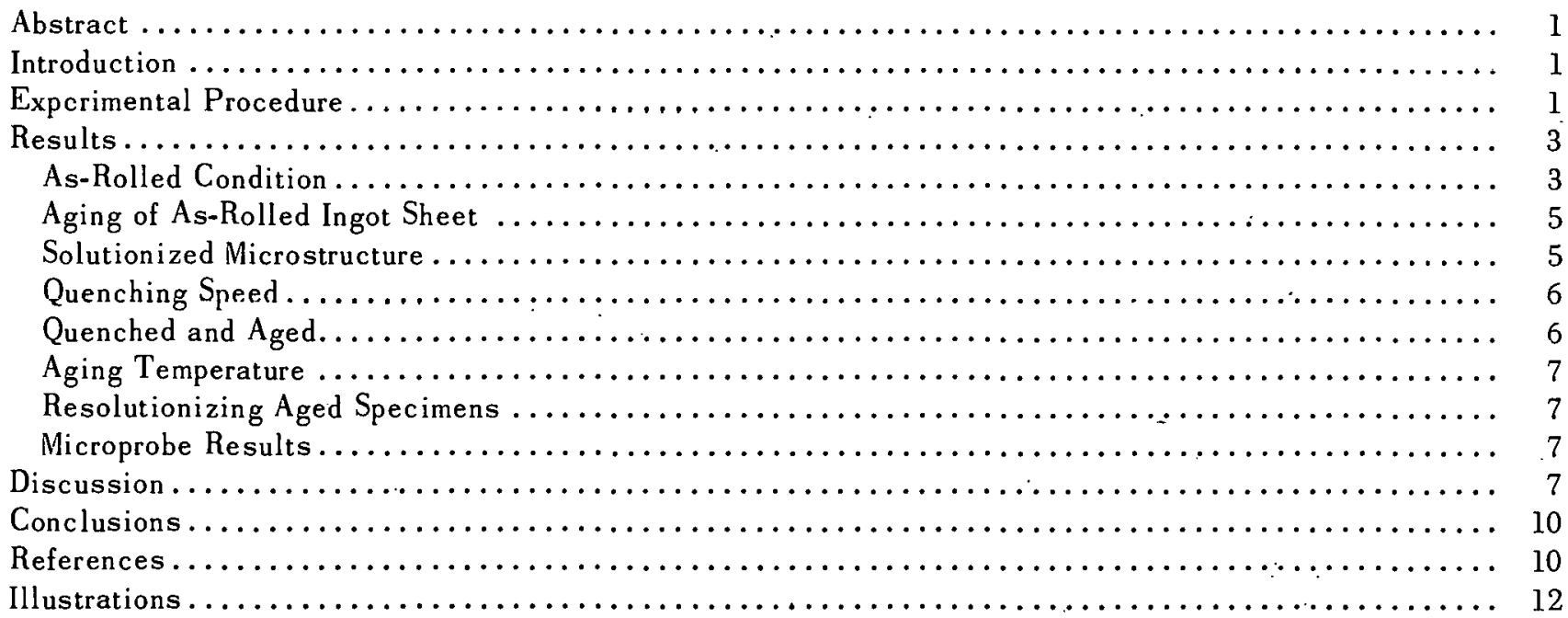




\section{ACKNOWLEDGMENTS}

Appreciation is expressed to J: L. Frankeny, D. R. Floyd, W. Leslie, and W. Leveritt for material and helpful suggestions; to M. R. Harvey and D. H. Riefenberg for the microprobe data; to C. A. Caldwell for chemical analyses; and to J. E. Pavlick and R. L. Moment for revicwing and discussing the subject data. 


\section{E R R A T A}

\section{PRECIPITATION CHARACTERISTICS OF ROCKY FLATS BERYLLIUM INGOT SHEET}

Frederick J. Fraikor, Virgil K. Grotzky, Arvel W. Brewer, and Howard E. Reed

RFP-1041 issued March 12, 1968

The following changes should be made on pages as indicated:

Page 1: Column 2, Paragraph 5, line 4, changes underlined to read:

"run. A calibrated chromel-alumel thermo-"

Page 8: Column 1, Notations at left of Equation 2 should read:

Overaged Condition

In-Grain Boundaries

$\left[\begin{array}{l}\mathrm{Al} \\ \mathrm{Si}\end{array}\right]$

$\left[\begin{array}{c}\mathrm{Fe} \\ \mathrm{Mn} \\ \mathrm{Ni} \\ \mathrm{Cr}\end{array}\right]$

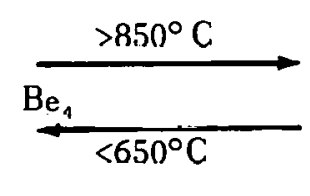

$\left[\begin{array}{l}\mathrm{Al} \\ \mathrm{Si}\end{array}\right]$

Pagc 11: Column 2, Reference No. 21, change to read:

21. V. D: Scott and H. M. Lindsay. "Some Electron Microscope Obsêrvations on Precipitation in Beryllium." Pages 145-177.

Beryllium Technology. Volume 1. Editors, I.. M. Schetcky and H. A. Johnson. Metallurgical Society Conferences. Volume 33. Gordon and Breach Science Publishers, New York. 1966.

Page 11: Column 2, Reference 22, change to read:

है

22. J. A. Carrabine, et al. "The Effect of $\mathrm{AlFeBe}_{4}$ on Mechanical Properties of Fabricated Polycrystalline Beryllium." Pages 239257. Beryllium Technology. Volume 1. Editors, L. M. Schetky and H, A. Johnson. Metallurgical Society Conferences. Volume 33. Gordon and Breach Science Publisliers, New York. 1966. 
RFP-1041

\section{Precipitation Characteristics of Rocky Flats Beryllium Ingot Sheet}

Frederick J. Fraikor, Virgil K. Grotzky, Arvel W. Brewer, and Howard E. Reed

\begin{abstract}
An investigation was conducted, principally by electron-transmission microscopy, of the types, morphology, and behavior of precipitates in typical ingot-sheet beryllium produced at the Rocky Flats Plant. Specific emphas is was placed on observing precipitation produced by the time and temperature parameters enc ountered during beryllium $(\mathrm{Be})$ sheet production.
\end{abstract}

Depending on the specific heat-treatment history of the beryllium sheet, results show that the predominant precipitates found in the microstructures are either of the ternary [aluminum--M--beryllium $4\left(\mathrm{AlMBe}_{4}\right)$ ], or of the binary type $\left[M-\right.$-beryllium $\left.11\left(\mathrm{MBe}_{11}\right)\right]$. In the notations, the symbol $M$ represents one of the transition elements as iron $(\mathrm{Fe})$, chromium $(\mathrm{Cr})$, nickel $(\mathrm{Ni})$, or manganese $(\mathrm{Mn})$. The precipitation reactions for Rocky Flats beryllium have been summarized in the report as a graphic equation.

\section{INTRODUCTION}

Several studies have been made on aging phenomena and precipitation behavior in beryllium (1 through 12$).^{1}$ In general, such studics have been concentrated on hot-pressed or extruded powdered commercial product, or on beryllium of significantly different composition than the type produced at the Rocky Flats Plant.

Therefore, a thorough investigation of precipitation in Rocky Flats ingot-sheet beryllium was conducted in order to: (a) provide a definitive understanding of the behavior of precipitates in beryllium ingot sheet with heat treatments typical of rolling procedures at Rocky Flats; and (b) to lead to possible future modifications of the heat treatments.

\section{EXPERIMENTAL PROCEDURE}

The starting material for the experiments included Rocky $\mathrm{F}$ lats beryllium ingot sheet in thicknesses varying from 0.001 to 0.005 inches of bare-rolled foil to 0.225 inches of beryllium (Be) sheet. Typical analyses of the Be are shown in Table I. A number of analyses on the major impurities were duplicated in an effort to determine any variations in the data produced by routine analysis. The iron-aluminum (Fe-Al) content ratio appeared somewhat dependent on the analysis technique.

As noted in Table II, the data from the original analysis show that while the $\mathrm{Fe}-\mathrm{Al}$ ratio was about 9 to 1 , the ratio was approximately $l$ to $l$ when both impurity levels were determined by the same technique. In the original analysis, the Al content was found by spectroscopic means and the $\mathrm{Fe}$ content from chemical analysis.

The ingot sheet in the as-received condition (noted as as-rolled throughout the report) refers to sheet obtained directly after rolling with no post-rolling heat treatment or flattening operations. In general, the as-rolled sheet had been etched to remove surface oxides and any remainder of rolling lubricant.

All heat treatments of the as-rolled Be specimens were conducted in a high-purity argon atmosphere furnace. The argon gas used for the experiments was Matheson ultrahigh purity ( 99.999 percent minimum) grade. A cylinder analys is is presented in Table III. As an additional precaution against water vapor, the gas was passed through purging bottles of magnesium-perchlorate anhydrous Drierite, ${ }^{2}$ and heated titanium-metal chips before entering the furnace tube. If rapid quenching of a particular sample had to be made, the furnace was tilted and the specimen dropped into a brine bath at 0 to $-10^{\circ} \mathrm{C}$. Argon flow was maintained at all times during the quench.

Generally, at least one specimen of the 501174-A

(3 mil) foil and another of the thick 176-CN $(0.225$ inches) sheet were placed in the furnace for each run. A calibrated chromium-aluminum ( $\mathrm{Cr}-\mathrm{Al})$ thermocouple was placed adjacent to the samples in the furnace tube. The foil was subsequently thinncd for examination by electron-transmission microscopy and the sheet specimen mounted for optical metallography and microhardness tests. However, a number of the

\footnotetext{
${ }^{2}$ Anhydrous calcium sulfate $\left(\mathrm{CaSO}_{4}\right)$.
} 
TABLE I. Analysis of 0.225 -Inch Thick Beryllium Ingot Sheet.

\begin{tabular}{|c|c|c|c|}
\hline Impurity & $\begin{array}{l}\text { Original Analysis } \\
\text { Lot No. } 176 \mathrm{CN} \\
\text { (weight percent) }\end{array}$ & $\begin{array}{l}\text { Second Analysis } \\
\text { Lot No. } 176 \mathrm{CN} \\
\text { (weight percent) }\end{array}$ & $\begin{array}{l}\text { *Third Analysis } \\
\text { Lot No. } 176 \mathrm{CN} \\
\text { (weight percent) }\end{array}$ \\
\hline Aluminum (Al) & 0.050 & 0.080 & 0.060 \\
\hline Beryllium Oxide $(\mathrm{BeO})$ & $* * 0.26$ & & *** 0.050 \\
\hline Carbon $(C)$ & $* * 0.065$ & & \\
\hline Calcium (Ca) & $<0.001$ & 0.008 & 0.003 \\
\hline Cadmium (Cd) & $<0.001$ & 0.008 & $<0.001$ \\
\hline Cobalt (Co) & $<0.001$ & 0.001 & $<0.001$ \\
\hline Chromium (Cr) & 0.015 & 0.020 & 0.015 \\
\hline Copper (Cu) & 0.020 & 0.050 & 0.008 \\
\hline Iron $(\mathrm{Fe})$ & $* * 0.185$ & 0.250 & 0.150 \\
\hline Magnesium (Mg) & 0.004 & 0.007 & 0.002 \\
\hline Manganese (Mn) & 0.018 & 0.013 & 0.025 \\
\hline Molybdenum (Mo) & $<0.001$ & $<0.001$ & $<0.001$ \\
\hline Nitrogen $(N)$ & $* * 0.006$ & & \\
\hline Nickel (Ni) & 0.025 & 0.013 & 0.025 \\
\hline Lead (Pb) & 0.001 & 0.002 & $<0.001$ \\
\hline Silic on (Si) & 0.060 & 0.070 & 0.050 \\
\hline 'l'itanium ('l'i) & 0.020 & 0.039 & 0.010 \\
\hline Tungsten $(w)$ & $<.0 .010$ & $<0.010$ & $<0.010$ \\
\hline Zinc $(Z n)$ & $<0.010$ & $<0.010$ & $<0.010$ \\
\hline
\end{tabular}

\footnotetext{
*Analyzed after the following heat treatment: Quenching Temperature $\left(\mathrm{T}_{\mathrm{Q}}\right)=1100^{\circ} \mathrm{C}$, and Annealing Temperature $\left(T_{A}\right)=780^{\circ} \mathrm{C}$ for one hour.

** Chemical analysis; all others by spectroscopic analysis.
} *** Neutron activation analysis.

TABLE II. Analysis of Three-Mil Beryllium Ingot Fuil.

\begin{tabular}{|c|c|c|c|c|}
\hline Impurity & $\begin{array}{l}\text { Original Analysis } \\
\text { Lot No. 501174-A } \\
\text { (weight percent) }\end{array}$ & $\begin{array}{l}\text { Second Analysis } \\
\text { (weight percent) }\end{array}$ & $\begin{array}{c}\text { Third Analysis } \\
\text { (weight percent) }\end{array}$ & $\begin{array}{l}\text { Fourth Analysis } \\
\text { (weight percent) }\end{array}$ \\
\hline Aluminum (Al) & 0.0225 & 0.060 & & $* * 0.128$ \\
\hline Beryllium Oxide (Ren) & $* * 0,16$ & & $* * 0.6 \dot{8}$ & \\
\hline Carhon (C) & $* * 0.078$ & & $* * 0.160$ & \\
\hline Calcium (Ca) & $<0.002$ & 0.002 & & \\
\hline Cadmium (Cd) & $<0.002$ & $<0.001$ & & \\
\hline Cobalt (Co) & $<0.002$ & 0.001 & & \\
\hline Chromium (Cr) & 0.015 & 0.009 & & \\
\hline Copper $(\mathrm{Cu})$ & 0.0125 & 0.008 & & \\
\hline Iron $(\mathrm{Fe})$ & $* * 0.188$ & 0.050 & & $\begin{array}{r}* 0.150 \\
* * 0.156\end{array}$ \\
\hline Magnesium (Mg) & 0.002 & 0.001 & & \\
\hline Manganese (Mn) & 0.009 & 0.010 & & \\
\hline Molybdenum (Mo) & $<0.003$ & $<0.001$ & & \\
\hline Nitrogen (N) & $* * 0.009$ & & · & \\
\hline Nickel (Ni) & 0.020 & 0.023 & & \\
\hline Lead $(P b)$ & $<0.002$ & $<0.001$ & • & \\
\hline Silic on $(S i)$ & 0.0125 & 0.040 & $* * 0.050$ & \\
\hline litanium $(T i)$ & 0.0115 & 0.013 & & \\
\hline Tungsten (W) & $<0.010$ & $<0.010$ & & \\
\hline $\operatorname{Zinc}(Z n)$ & $<0.008$ & $<0.010$ & & \\
\hline
\end{tabular}

* Atomic absorption analysis.

** Chemical analysis; all other by spectroscopic analysis. 
TABLE III. Analysis of Cylinder No. $36626 \mathrm{~T}$ Matheson Ultrapure Argon-Ionization Grade.

\begin{tabular}{lr} 
Gas & $\begin{array}{r}\text { Parts per } \\
\text { Million }\end{array}$ \\
\cline { 2 - 2 } $\begin{array}{l}\text { Carbon Dioxide }\left(\mathrm{CO}_{2}\right) \\
\text { Oxygen }\left(\mathrm{O}_{2}\right)\end{array}$ & $<0.5$ \\
Hydrogen $\left(\mathrm{H}_{2}\right)$ & $<2.0$ \\
Carbon Monoxide (CO) & $<1.0$ \\
Nitrogen $\left(\mathrm{N}_{2}\right)$ & $<0.5$ \\
Water $\left(\mathrm{H}_{2} \mathrm{O}\right)$ & $<2: 0$ \\
Methane $\left(\mathrm{CH}_{4}\right)$ & $<2.0$ \\
\multicolumn{1}{c}{$\mathrm{NO}^{\prime} \mathrm{TE}:$ Argon-ionization grade: } \\
99.999-percent minimum. \\
(The Matheson Company, \\
Joliet, Illinois.)
\end{tabular}

0.225 -inch thick specimens were sliced by a diamond saw or a chemical saw; then thinned to verify that the microstructure was similar to the one produced during the same heat treatment in the thinner 3-mil foil. A series of foils were also mounted for Knoopmicrohardness tests.

The Be foils for electron-transmission microscopy were thinned in a Glenn-Dual-Jet thinning unit. ${ }^{3}$ The electrolyte consisted of 400 milliliters $(\mathrm{ml})$ of ethylene glycol, $40 \mathrm{ml}$ of nitric acid $\left(\mathrm{HNO}_{3}\right), 8 \mathrm{ml}$ of sulfuric acid $\left(\mathrm{H}_{2} \mathrm{SO}_{4}\right)$, and $8 \mathrm{ml}$ of hydrochloric acid (HCl). About 900 milliamperes of current at 36 volts were used. The electrolyte was kept at a temperature of 10 to $15^{\circ} \mathrm{C}$ by a circulating ice bath.

The thinned foils were immersed and rinsed in distilled water and methyl alcohol, mounted between 75-mesh copper grids, and examined at 100 kilovolts (kv) in the Phillips EM-200 unit.

Frain-size measurements and optical metallography were concurrently performed on mountcd Be specimens with an electropolishing and etching technique, devised for examination of Be microstructure under bright-field illumination (13).

\section{RESULTS}

As-Rolled Condition: The history of Billet No. 501174-A is shown in Table IV. Note that the important parameters include an initial solutionizing treatment of $1038^{\circ} \mathrm{C}$ $\left(1900^{\circ} \mathrm{F}\right)$ for 10 hours and final bare-rolling passes at $780^{\circ} \mathrm{C}\left(1436^{\circ} \mathrm{F}\right)$ and $740^{\circ} \mathrm{C}\left(1364^{\circ} \mathrm{F}\right)$. A lthough the recrystallization temperature of $\mathrm{Be}$ has been reported

\footnotetext{
${ }^{3}$ Commercially available from Glenn Electronics and Mechanical Specialties, Incorporated, Jeannette, Pennsylvania.
}

in the range of 600 to $800^{\circ} \mathrm{C}(14,16)$, it is readily apparent from the photomicrographs ${ }^{4}$ in Figures 1 and 2, that the dislocation microstructure consists of dislocation subboundaries. Little or no recrystallization has occurred during and immediately after the final bare-rolling operation. Such results are expected since the relatively high-thermal conductivity of $\mathrm{Be}$ and the contact of cold rolls on thin sheet provide for a rapid drop in the actual sheet temperature. The final pass is probably well below the recrystallization temperature and a warm-worked substructure is produced. Optical metallography confirmed that only partial recrystallization had occurred in a much thicker Be sheet (Figure 3 ). The subgrains are 1 to 5 microns in approximate diameter although the size varies considerably depending on the thermal and rolling history of each particular billet.

Figure 4 shows a higher magnification photomicrograph of a typical subboundary dislocation structure in the as-rolled sample. The process of recovery through migration and elimination of dislocations within the subgrains has begun and the cell walls are assuming a more metastable, narrow configuration. Note the fringe associated with a subboundary at (a) in the center of the photomicrograph.

Lindsay and Scott (17) have shown dislocations with nonbasal Burgers vectors of $1 / 3<11 \overline{2} 3\rangle$ in dislocation arrays found in Pechiney electrolytic-flake Be rolled at $650^{\circ} \mathrm{C}$. The structures are similar to those shown in Figures 1 and 2. Probably, the nonbasal slip dislocations contribute to the increased formability (compared to room temperature) observed during rolling at the given temperatures. Note the directions and planes in hexagonal close-packed $\mathrm{Be}$ in Figure 5.

In addition to the cellular structure, globular precipitate particles about 5000 angstroms $(\AA)$ in diameter were found scattered intermittently throughout the microstructure of the rolled $\mathrm{Be}$ ingot sheet (Figure 6 ). The particles were identified by electron-diffraction patterns as mainly of the ternary type termed $\mathrm{AIFeBe}_{4}$ by Carrabine (5) or $\mathrm{Be}_{5}(\mathrm{Fe}, \mathrm{Al})$ by Rooksby (4) with a face-centered cubic lattice parameter of approximately $6.05 \AA$. Some of the precipitates are associated with subboundaries (Figure 7).

A few much larger beryllium oxide $(\mathrm{BeO})$ inclusions were found also during examination of the rolled

\footnotetext{
${ }^{4}$ See illustrations at end of text, Page 12.
} 
RFP-1041

TABLE IV. History of Casting.

Casting History:

Billet No. 501174-A

Material Used - 7-kilogram skull (ingot top)

29-kilogram in got sheet scrap, solid

10-kilogram Oak Ridge powder scrap

Canned - Type-304 stainless steel covers (5/8 jpches thick)

Solutionized 10 hours at $1900^{\circ} \mathrm{F}\left(1038^{\circ} \mathrm{C}\right)$

Rolling Schedule (canned):

\begin{tabular}{|c|c|c|c|c|}
\hline Pass & $\begin{array}{c}\text { Mill Setting } \\
\text { (inches) }\end{array}$ & $\begin{array}{c}\text { Hot Micrometer } \\
\text { Reading } \\
\text { (inches) } \\
\end{array}$ & Remarks & \\
\hline \multirow{3}{*}{$\begin{array}{r}1 \\
2 \\
3 \\
4 \\
5 \\
6 \\
7 \\
8 \\
9 \\
10 \\
11 \\
12 \\
13 \\
14 \\
15 \\
16 \\
17 \\
18 \\
19 \\
20 \\
21\end{array}$} & \multirow{3}{*}{$\begin{array}{l}4.450 \\
4.150 \\
3.850 \\
3.550 \\
3.250 \\
2.950 \\
2.650 \\
2.350 \\
2.050 \\
1.800 \\
1.550 \\
1.300 \\
1.100 \\
0.900 \\
0.750 \\
0.650 \\
0.550 \\
0.450 \\
0.350 \\
0.280 \\
0.2\end{array}$} & & $\begin{array}{l}90^{\circ} \text { clockwise } \\
90^{\circ} \text { clockwise } \\
90^{\circ} \text { clockwise } \\
90^{\circ} \text { clockwise }\end{array}$ & \\
\hline & & & Reheat $1900^{\circ} \mathrm{F}$ (25 minutes) & \\
\hline & & • & $\begin{array}{l}90^{\circ} \text { clockwise } \\
90^{\circ} \text { clockwise } \\
90^{\circ} \text { clockwise } \\
90^{\circ} \text { clockwise } \\
\text { Reheat } 1800^{\circ} \mathrm{F} \text { (30 minutes) turn over OK } \\
90^{\circ} \text { clockwise } \\
\text { Rcheat } 1750^{\circ} \mathrm{F} \text { ( } 15 \text { minutes) } \\
90^{\circ} \text { clockwise } \\
\text { Reheat } 1600^{\circ} \mathrm{F} \text { (35 minutes) } \\
\text { Turn } 90^{\circ} \text { OK } \\
\text { Reheat } 1550^{\circ} \mathrm{F} \text { (15 minutes) } \\
\text { Reheat } 1550^{\circ} \mathrm{F} \text { (10 minutes) } \\
\text { Reheat } 1450^{\circ} \mathrm{F} \text { (10 minutes) turn over } \\
\text { Reheat } 1450^{\circ} \mathrm{F} \text { (10 minutes) }\end{array}$ & \\
\hline
\end{tabular}

NOTE: To storage at $1430^{\circ} \mathrm{F}$ for 20 hours. Hot-sheared and sta inless steel cans removed. Shcet thickuess 0.170 inches.

Bare Rolling Schedule (starting thickness 0.170 inches):

$\begin{array}{llll}1 & 0.170 & 0.170 & \text { Sheet rotated } 90^{\circ} \text { and unidirectionally rolled } \\ 2 & 0.150 & 0.155 & \\ 3 & 0.135 & 0.143 & \text { A 12-minute reheat between each pass at } 1400^{\circ} \mathrm{F} \\ 4 & 0.120 & 0.130 & \\ 5 & 0.105 & 0.117 & \\ 6 & 0.090 & 0.104 & \\ 7 & 0.080 & 0.092 & \\ 8 & 0.070 & 0.083 & \\ 9 & 0.062 & 0.076 & \end{array}$

NOTE: Sheet No. 501174, Billet A cut into 5-inch squares for bare-rolling on the Stanat rolling mill.

Stanat Bare-Rolling Schedule:

\begin{tabular}{llll}
\hline 1 & 0.009 & 0.011 & A 5 -minute reheat between each pass $\left(780^{\circ} \mathrm{C}\right)$ \\
2 & 0.063 & 0.066 & \\
3 & 0.057 & 0.061 & A $90^{\circ}$-clockwise rotation after each pass \\
4 & 0.051 & 0.058 & 0.051
\end{tabular}

0.045

$0.039 \quad 0.046$

$0.034 \quad 0.040$

$0.029 \quad 0.036$

$0.025 \quad 0.031$

$0.021 \quad 0.028$

$0.017 \quad 0.025$

$0.013 \quad 0.021$

$0.011 \quad 0.018$

$0.009 \quad 0.016$

$0.008 \quad 0.015$

$0.006 \quad 0.013$

$0.005 \quad 0.011$

closed 0.0075

closed 0.0075

closed 0.007

closed

0.006

$\begin{array}{ll}\text { closed } & 0.007 \\ \text { clused } & 0.0065\end{array}$

closed $\quad 0.0055$

closed

closed $\quad 0.0050$

clused $\quad 0.0048$

closed $\quad 0.0045$

closed $\quad 0.0040$

closed $\quad 0.0045\}$

closed $\quad 0.0040$

closed $\quad 0.0040$

closed $\quad 0.0038$

closed $\quad 0.0038$

Random pieces of beryllium checked with micrometer after each pass

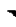

All beryllium cleaned with beryllium etchant of equal volume of distilled water $\left(\mathrm{H}_{2} \mathrm{O}\right)$ and nitric acid $\left(\mathrm{HNO}_{3}\right)$ plus one percent by volume of 48 percent hydrofluoric (HF) acid, based upon the $\mathrm{HNO}_{3}$ volume used. Mill cleaned after each pass with perchloroethylene, and muffle temperature was set at $740^{\circ} \mathrm{C}$ when beryllium was at 0.005 inches. Low tolling speed and no lubrication. 
foils. These generally served as areas however of preferential attack during the thinning operation, thus leaving only voids and pits. Oxide inclusions in ingot sheet of vacuum-cast origin such as at Rocky Flats are much less predominant than in powder material and evidently do not play a dominant role in the recrystallization (14).

Aging of As-Rolled Ingot Sheet: Since the current rolling schedules of $\mathrm{Be}$ ingot sheet require an overaging treatment at $780^{\circ} \mathrm{C}$ for 20 hours, a series of as-rolled sheet samples were heat-treated in the argon furnace at $780^{\circ} \mathrm{C}$ for various times ranging from 5 minutes to 72 hours. The optical photomicrographs (Figures 8 through 11) show that the elimination of subboundaries were generally complete within 1 to 3 hours at this temperature. The photomicrographs also reveal a minimum of subsequent grain growth. The grain size as a function of time is listed in Table V. Only a small amount of grain growth over a 20-hour period is to be expected since the aging temperature is relatively low.

TABLE V. Grain Size Versus Aging Time at $780^{\circ} \mathrm{C}$ for 0.225 -Inch Beryllium Ingot Sheet.

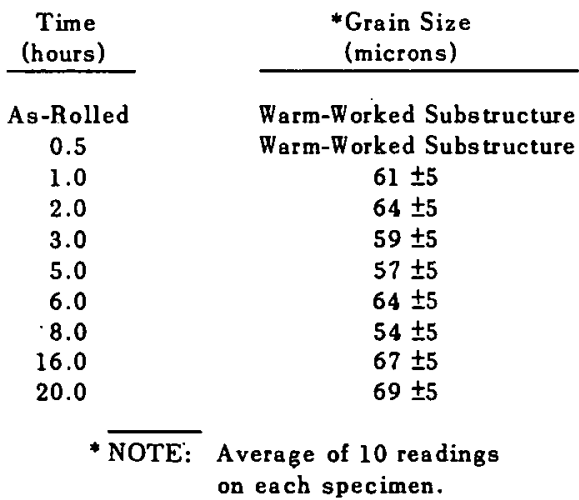

The electron-transmission photomicrographs of the rolled-beryllium ingot sheet after one hour at $780^{\circ} \mathrm{C}$ are show $n$ in Figures 12 and 13. Figure 12 illustrates a row (arrow) of irregular and round precipitates (probably $\mathrm{AlFeBe}$ ) within a subboundary. Platelets (6), identified as $\mathrm{FeBe}_{11}$, are shown in $\mathrm{Figure} 13$, although these were relatively uncomm on $w$ ith in the substructure after the heat treatment, as compared to the irregular and round shapes of the ternary, AlMBe, type.

Additional time at the aging temperature produced complete recrystallization in some specimens, accompanied by grain growth. In some instances, the result showed remaining rows of precipitates, which originally had been nucleated at subboundaries. (Compare Figures 14 and 15 with the row of precipitates in Figure 12.)
Other precipitates were more successful in inhibiting grain-boundary migration (Figure 16). Generally, however, the microstructure consisted of round and irregular particles and random plates throughout the matrix of the grains. Diffraction patterns from larger, irregular-shaped matrix precipitates were indexed as $\mathrm{AlMBe}_{4}$ types. It is presumed that the smaller precipitates associated with the grain boundaries were also $\mathrm{AlFeBe}_{4}$.

Little change in precipitate size or morphology was noted with still longer-aging times. Growth was indicated of larger precipitates at the expense of smaller ones, accompanied by a slight reduction in precipitate density in the samples aged for 70 hours. Oxide coatings and preferential pitting presented severe problems for thining these specimens.

Solutionized Microstructure: The next step was to examine specimens quenched from the vicinity of the ingot solutionizing temperature (about $1038^{\circ} \mathrm{C}$ for 501174-A sheet, Table IV). A series of Be-ingot sheet specimens were quenched into brine from the argon-atmosphere furnace from temperatures of 850,900 , 1000,1100 , and $1200^{\circ} \mathrm{C}$ and examined under the electron microscope.

The first photomicrograph (Figure 17) from these elevated temperature quenches shows a number of small, often lenticular-shaped precipitates in the grain boundaries. The aluminum or aluminum-rich precipitates $(19,20)$ measured less than $2000 \AA$ in length and were observed in all of the ingot-sheet specimens quenched from $900^{\circ} \mathrm{C}$ and above, particularly at grain-boundary intersections.

Low $\mathrm{Al}$ content in the Be did not preclude the formation of the grain-boundary precipitates. Figure 18 shows the same precipitates in high-purity $(99.85$ percent $\mathrm{Be}$ ) ingot foil with less than 0.015 weightpercent $(w / o)$ aluminum. The analysis of the sheet made by the manufacturer ${ }^{5}$ is presented in Table VI.

The matrix of the grains in the quenched specimens contained few precipitates other than BeO inclusions, but were marked by a profusion of dislocation loops, dipoles, and helical dis locations (Figures 19 and 20). Two of three possible orientation sets of $1 / 3<11 \overline{2} 0\rangle$ prismatic dislocation loops are shown in $F$ igure 19. Note the interaction between adjacent loops at (a).

\footnotetext{
${ }^{5}$ The Beryllium Corporation (Berylco), Hazelton, Pennsylvania.
} 
TABLE VI. Analysis of High-Purity Beryllium Ingot Foil.

Berylco Sheet No. $30 \mathrm{~B}(0.005$ by 4 by 6 inches)

\begin{tabular}{lr}
\multicolumn{1}{c}{ Material } & $\begin{array}{c}\text { Weight } \\
\text { Percent }\end{array}$ \\
\hline Beryllium Assay & 99.85 \\
Beryllium Oxide (BeO) & 0.17 \\
Carbon (C) & 0.011 \\
Iron (Fe) & $<0.015$ \\
Aluminum (Al) & $<0.015$ \\
Manganese.(Mg) & $<0.003$ \\
Silicon (Si) & 0.025
\end{tabular}

NOTE: All other metallic impurities, 0.04 maximum.

Cross slip of one portion of a disloc ation loop to an adjacent $(11 \overline{2} 0)$ plane has occurred at (a) in Figure 20. The photomicrograph also shows the possible interaction of these loops with a $<11 \overline{2} m$ srrew dis looation to form a helical $1 / 3<11 \overline{2} 0\rangle$ dislocation at (b).

Increased time (more than 4 hours) at the solutionizing temperature produced a decrease in the number of small grain-boundary precipitates with a corresponding increase in the size of a few aluminum-rich particles. Since grain growth was fairly rapid at these elevated temperatures, some of the large aluminum-rich precipitates were also found in the matrix adjaccnt to the grain boundaries. Quenching from lower temperatures, such as $850^{\circ} \mathrm{C}$ produced a mixture of round matrix precipitates with a few grain-boundary intersection particles. One large matrix precipitate produced an $\mathrm{AlMBe}_{4}$ diffraction pattern.

Quenching Speed: A variable generally not studied is the effect of quenching speed on the precipitation characteristics of $\mathrm{Be}$. It was found that extremes of the variable did alter the precipitates which appeared in solutlonized specimens. As noted in the previous sestion, small Al grain-boundary precipitates characterized Be ingot sheet, brine-quenched from the elevated tempcratures. The result represents a rapid quench condition.

Similar results were obtained from a somewhat slower quench by removing 0.003 -inch thick specimens from the center of the hot furnace to the end of the tube and allowing them to argon-cool to room temperature (Figure 21). The thin foils would be expected to cool quickly.

With a much slower cooling condition (approximately $5^{\circ} \mathrm{C}$ per minute), attained by allowing the specimens to cool with the furnace overnight, the grain-boundary precipitates were generally larger (up to one micron in length) (Figure 22). Diffraction patterns obtained from the precipitates indicate the phase was again of the type termed, $\mathrm{Be}_{5}$ (Fe, Al), by Rooksby (4) or $\mathrm{AlFeBe}_{4}$ by Carrabine (5). If the furnace-cooled specimen was subsequently reheated and hcld at $1000^{\circ} \mathrm{C}$ and brinequenched, the aluminum-rich lenticular precipitates reappeared as shown in Figure 23. The grain-boundary precipitates were somewhat larger (about $1500 \AA$ ) than those previously shown in the as-quenched condition (Figure 17). The density (number of precipitates per cubic centimeter) of grain-boundary precipitates was drastically reduced.

As might be expected, recrystallization and grain growth were fairly rapid at these elevated temperatures. Figure 24 is an optical photomicrograph of the grain size at the Rocky Flats Be ingot sheet annealed at $1000^{\circ} \mathrm{C}$ for 15 minutcs. The average grain size for these conditions was about 100 to 200 microns.

Quenched and Aged: Specimens, which had been brine-quenched from the elevated solutionizing temperatures and subsequently aged at $780^{\circ} \mathrm{C}$-for varying times greater than one minute (Figure 25 ), revealed a precipitation of $\mathrm{FeBe}_{11}$ in the matrix.

The precipitation reaction was rapid. Platelets were noted in quenched specimens which had been aged for only five minutes at $780^{\circ} \mathrm{C}$ (Figures 25 and 26). (Note: All brine-quenched specimens were retained below $0^{\circ} \mathrm{C}$ until returned to the furnace at $780^{\circ} \mathrm{C}$. After the required a ging time, the samples were quenched into distilled water at room temperature.)

Further aging for one hour at this temperature clearly revealed matrix precipitates of $\mathrm{FeBe}_{11}$ platelets up to $5000 \AA$ in length (Figures 27 through 30 ). The microstructure is different from the as-rolled $780^{\circ} \mathrm{C}$ aging treatmeni prevlously described, since few large globular precipitates of the ternary type, $\mathrm{AlMBe}_{4}$, were found in the matrix of the brine-quenched and aged specimens. Instead, the predominant matrix precipitate was the $\mathrm{FeBe}_{11}$ platelet in all samples brine-quenched from $900^{\circ} \mathrm{C}$ or above (Figures 31 and 32 ).

Quenching from lower temperatures, however did not produce the $\mathrm{FeBe}_{11}$ predominance upon subsequent aging. For example as expected, few plate precipitates were found in specimens brine-quenched from $780^{\circ} \mathrm{C}$ and aged at $780^{\circ} \mathrm{C}$ for one hour. Instead, round and irregular ternary precipitates were observed (Figure 33 ). Similar results were obtained from ingot sheet quenched from $850^{\circ} \mathrm{C}$ and aged at $780^{\circ} \mathrm{C}$. The larger particles produced electron-diffraction patterns which could be indexed as the ternary type, $\mathrm{AlMBe}_{4}$. 
Quenching speed was varied to observe any microstructure changes in the quenched and aged specimens. If the specimen was furnace-cooled (instead of brinequenched) from $1000^{\circ} \mathrm{C}$ at $13^{\circ} \mathrm{C}$ per minute to $225^{\circ} \mathrm{C}$ and then aged at $780^{\circ} \mathrm{C}$ (Figures 34 and 35), the precipitation consisted of $\mathrm{AlFeBe}_{4}$ at the grain boundaries and matrix with a few. rod (plate) $\mathrm{FeBe}_{11}$ precipitates. (Compare the rows of precipitates shown in Figures 34 and 35 with those in Figures 14 and 15.)

Furnace-cooling the specimen directly to $780^{\circ} \mathrm{C}$ and allowing it to remain in the furnace at $780^{\circ} \mathrm{C}$ for one hour produced large, (up to $10,000-\AA$ diameter) round and irregular-shaped ternary precipitates (Figure 36). Slightly faster cooling was achieved in the argon atmosphere at the end of the furnace tube and the heat treatment produced a mixture of $\mathrm{AlFeBe}$ and $\mathrm{FeBe}_{11}$ (Figure 37).

Aging Temperature: A number of specimens were brine-quenched from $1000^{\circ} \mathrm{C}$ and aged at $850^{\circ} \mathrm{C}$ for various times. In addition to the normal grainboundary precipitates, Figure 38 shows a relatively low density of large plates in the matrix. Aging brine-quenched specimens at $650^{\circ} \mathrm{C}$ for one hour produced smaller precipitates (Figure 39 ).

Still lower-aging temperatures $\left(500^{\circ} \mathrm{C}\right)$ did not show any significant matrix precipitates after the first hour of aging (Figures 40 and 41 ). Longer times ( 4 to 24 hours) did show precipitation in the matrix with strain contrast around the particles. The heat treatment and the resulting microstructure are currently being studied since the kinetics of precipitation are evidently much slower at this aging temperature than at $780^{\circ} \mathrm{C}$. Scoll and Liudsay (21) have roportod precipitation in various purity grades of beryllium at aging temperatures of 500 to $600^{\circ} \mathrm{C}$, but only after long-aging times on the order of 500 hours. These were not repeated with Rocky Flats ingot sheet, since such a long-heat treatment would probably not be commercially feasible.

Resolutionizing Aged Specimens: Specimens which were aged at $780^{\circ} \mathrm{C}$ from the as-rolled, warm-worked condition and subsequently reheated to $1000^{\circ} \mathrm{C}$ and quenched, simply show the as-quenched structure of aluminum-rich, grain-boundary precipitates with an absence of matrix precipitates. Other specimens in the quench-aged condition were also reheated to various temperatures, water=quenched, and examined under the microscope. Figure 42 shows one of the specimens which had previously been brine-quenched from $1000^{\circ} \mathrm{C}$, aged for one hour at $780^{\circ} \mathrm{C}$, and then resolutionized at $1000^{\circ} \mathrm{C}$ for one hour and waterquenched. The $\mathrm{FeBe}_{11}$ matrix precipitates which were so evident in the quenched-aged condition are completely gone and only a small aluminum precipitate remains. Similar results of dissolving $\mathrm{FeBe}_{11}$ were obtained by resolutionizing at $900^{\circ} \mathrm{C}$ (Figure 43). Using $850^{\circ} \mathrm{C}$ for the quench temperature, aging at $780^{\circ} \mathrm{C}$ and resolutionizing at $850^{\circ} \mathrm{C}$, however, produced large ternary precipitates; a number of which apparently were be ginning to coalesce (Figure 44).

The long, diffuse grain-boundary $\mathrm{AlFeBe}_{4}$ produced in furnace-cooled $\mathrm{Be}$ also disappeared at $1000^{\circ} \mathrm{C}$ (Figure 45), and left behind long, lenticular aluminumrich precipitates.

Microprobe Results: Only qualitative results were obtained from the electron microprobe since the precipitate particles were generally much smaller than the electron-beam width (approximately one micron). Occasionally, however, extremely large particles were found. Figure 46 shows an optical photomicrograph of beryllium sheet quenched in brine from $1100^{\circ} \mathrm{C}$ and aged at $780^{\circ} \mathrm{C}$ for one hour. Note the inclusions marked by the arrow near the grain-boundary intersection. The largest inclusion is about 0.03 millimeters in diameter. An aluminum$\mathrm{K}_{\text {(alpha) raster scan by the microprobe revealed a }}$ concentration of $\mathrm{Al}$ in these inclusions (Figure 47). A similar scan of iron- $\mathrm{K}_{a}\left(\mathrm{FeK}_{a}\right)$ revealed only a slight trace of $F_{c}$ in this region (Figure 48 ).

\section{DISCUSSION}

Several investigators $(22,23,24)$ have proposed that the dominant preripitation reaction in Be is an interaction of $\mathrm{Al}$ and $\mathrm{Fe}$. Carrabine, for example, demonstrated the interaction of $\mathrm{Fe}$ and $\mathrm{Al}$ on the mechanical properties of hot-pressed polycrystalline beryllium (22). $\mathrm{He}$ considered the determining factor on elevated temperature properties to be a reversible $\mathrm{AlFeBe} e_{4}$ precipitation reaction which could be directly related to the $\mathrm{Fe}$ to $\mathrm{Al}$ impurity ratio of the $\mathrm{Be}$ as in Equation 1 .

$$
\frac{\text { As Pressed or Aged }}{\mathrm{AlFeBe}_{4} \longleftarrow} \underset{(\text { free) (in solution) }}{\longrightarrow}
$$

Any $\mathrm{Al}$ in excess of the stoichiometric amount required to form $\mathrm{AlFeBe}_{4}$ was presumed to remain primarily in the grain boundaries. Confirmation has been reported (19) of graiu-boundary and aluminum.rioh precipitates in Rocky Flats ingot sheet, rapidly cooled from the temperature range of 900 to $1200^{\circ} \mathrm{C}$. 
Hanes and others (25) have proposed a modified solutionizing-aging reaction similar to Equation 1, but involving a number of transition elements as noted in Equation 2. The symbol $M$ represents one of the transition elements given in the equation.

Overaged.Condition In-Grain Boundaries In Solution

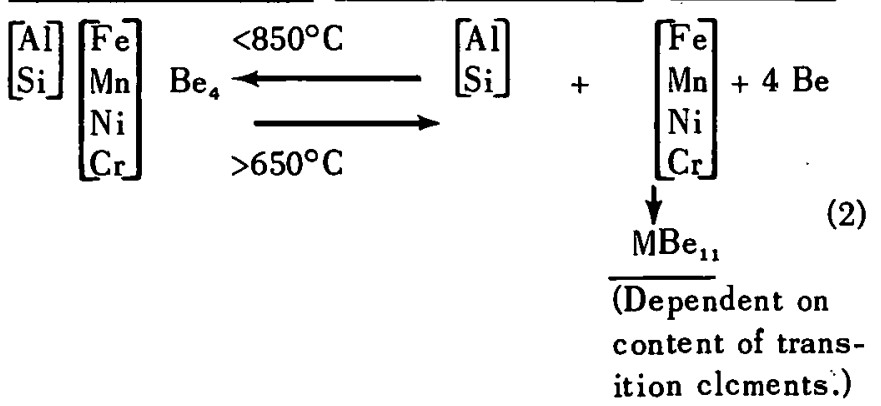

The equilibrium reaction and the associated temperatures in Equation 2 are based on the work summarized in the Battelle report (25). The results in the current investigation on Rocky Flats $B e$ ingot sheet indicate that the material appears to conform to the general form of Equation 2. Some modifications are necessary however, particularly when there is a departure from equilibrium conditions.

Therefore it is proposed that the precipitation reactions for Rocky Flats Be ingot sheet can be summarized graphically as in Equation 3:
Hence from Equation 3, prediction can be made of the microstructure expected from any particular combination of heat treatments which the Be sheet may undergo.

For example, if in considering, chronologically from Table IV, the first heat treatment after casting of Rocky Flats $\mathrm{Be}$ ingot sheet (a solutionizing treatment at $1038^{\circ} \mathrm{C}$, one might expect, on the basis of the electron-transmission photographs and Equation 3, that the microstructure would consist of free aluminum (Ai) and silicon $(\mathrm{Si})$ with the transition elements in solution. The role of free $\mathrm{Al}$ on malleability at these temperatures is still not clearly known. Some French investigators however have reported observing $\mathrm{Al}$ in the liquid molten state in ingot-source $\mathrm{Be}$ above $500^{\circ} \mathrm{C}(20)$.

The quenching studies in the current work show that grain-boundary $\mathrm{Al}$ may still be important even at room temperature, if the $\mathrm{Be}$ is rapidly cooled from above $900^{\circ} \mathrm{C}$. Even though the equilibrium equation (No. 2) predicts the formation of $\mathrm{AlMBe}_{4}$ below $650^{\circ} \mathrm{C}$, rapid quenching prevents significant solute diffusion of $\mathrm{Fe}$ to the grain boundaries. The speed of the quench need not be as rapid as for a thin foil quenched in

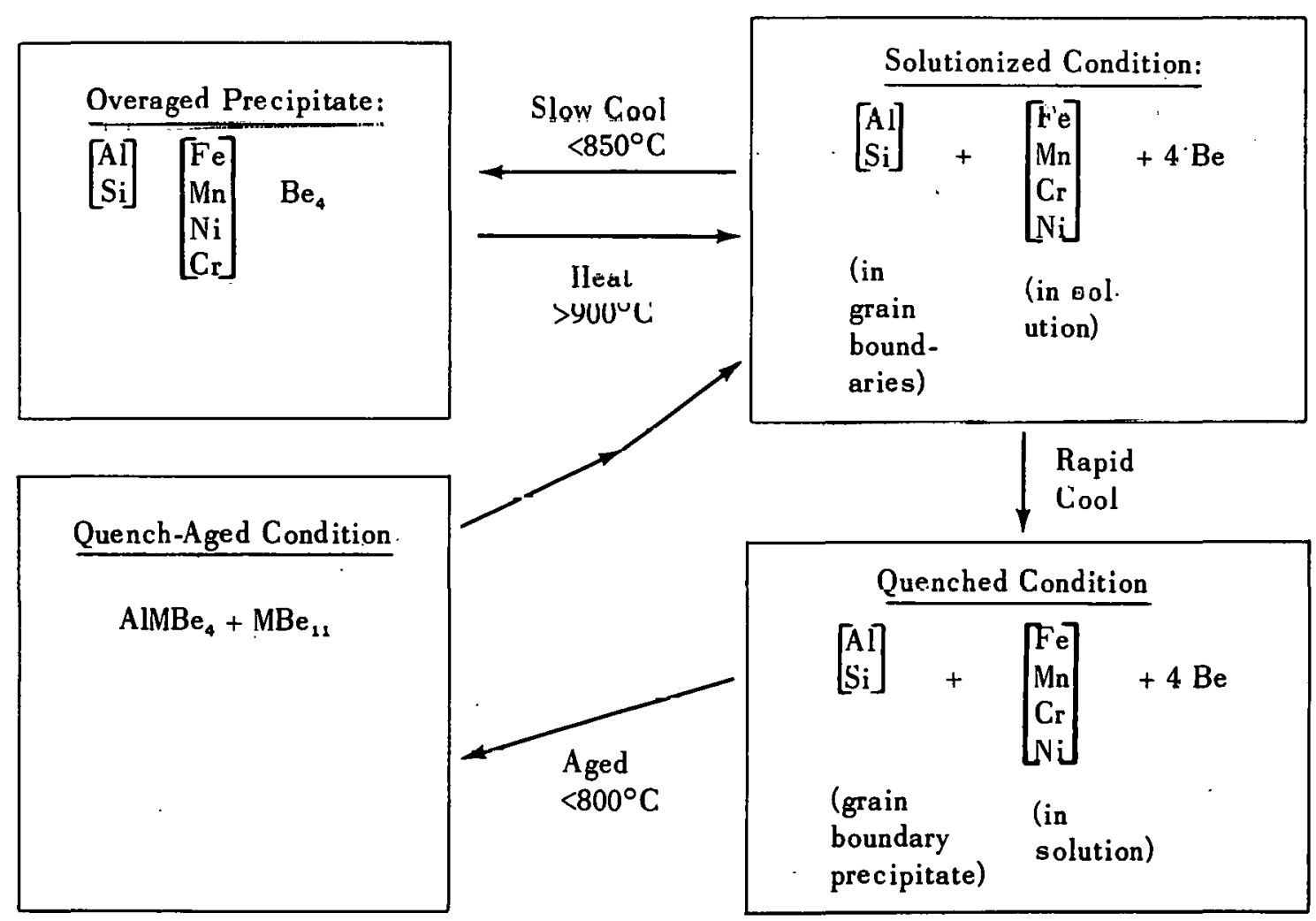


brine (estimated at about $\left(1 \times 10^{3}\right)$ to $\left(1 \times-10^{4}\right)$ degrees centrigrade per second, since the photomicrographs clearly show Al grain-boundary precipitates in atmosphere-cooled ingot sheet. Thus grain-boundary, aluminum-rich precipitates may be expected in instances such as some welding operation where fast cooling rates and high residual stresses may be encountered.

As the rolling operation continues with decreasing rolling temperatures (Table IV), ternary $\mathrm{AlMBe}_{4}$ precipitates form, particularly at favorable nucleation sites such as subboundaries, etc. One of the important parameters at this stage is the final actual rolling temperature of the sheet. The $\mathrm{AlFeBe}{ }_{4}$ particles are already formed throughout the structure and the final-rolling passes determine the extent and nature of the recovery and recrystallization during subsequent aging and annealing treatments. Although the term overaging is currently applied to the 20 -hour heat treatment at $780^{\circ} \mathrm{C}$, the transmission results show that the $\mathrm{AlFeBe}_{4}$ precipitates appear much the same in the as-rolled condition as they are after the 20 -hour aging treatment.

The only apparent difference in the aged structure is the elimination of subboundaries which in some instances leave behind a row of precipitate particles. However, some phenomena other than grow th of $\mathrm{AlFeBe}_{4}$ precipitates may be taking place, such as clustering of other elements "with slower diffusion rates. Some impurities may reside in the subgrains and the elimination of the subboundaries would then allow these constituents to interact with other lattice defects. Investigations are currently continuing at Rocky F lats to observe if any such phenomena actually take place during the $780^{\circ} \mathrm{C}$ aging treatment.

In the current report, the observed ternary precipitates $\left(\mathrm{AlMBe}_{4}\right.$ ) are given as $\mathrm{AlFeBe}_{4}$, simply because $\mathrm{Fe}$ is the predominant transition element in Rocky Flats Be ingot sheet. Electron diffraction of small precipitates cannot easily distinguish between $\mathrm{AlNiBe}_{4}$ with a lattice parameter (5) of $6.01 \AA$ and $\mathrm{AlFeBe}_{4}$ with a lattice parameter of $6.06 \AA$. The majority of patterns that were examined produced lattice parameters of 6.03 to $6.10 \AA$, but nearly all of these transition elements produce ternary precipitates with a lattice parame ter close to $6 \AA$ (5). Since the precipitates are much too small for analysis with a conventional microprobe, the exact role of each of the transition elements in Rocky Flats Be sheet cannot be exactly defined. However, the assumption is generally made that the diffusion of $\mathrm{Fe}, \mathrm{Mn}, \mathrm{Ni}$, and $\mathrm{Cr}$ in the Be lattice is approximately the same. Thus the precipitation kinetics of each $\mathrm{AIMBe}_{4}$ type are not significantly different.

Another area of investigation brought out by this study is the need to obtain a good correlation between mechanical properties of Rocky Flats ingot sheet and the microstructures produced by the various heat treatments. Similar correlations have been done on extruded powder. Be by Jac obson (29). Brine-quenching of thick Be pieces does not appear feasible because of quenching stresses. But air or inert-atmosphere cooling to room temperature of Be ingot sheet, followed by aging, would still produce the quench-aged microstructure of $\mathrm{AlMBe}_{4}$ and $\mathrm{MBe}_{11}$ plates.

It is unlikely that quench-aging or any other combination of heat treatments will provide a much greater increase in the room temperature ductility of ingot sheet. Nevertheless, they do offer alternatives for future exploration, particularly in dilute Be alloys.

It should be pointed out at this point that the term, quench-aging, of precipitation-hardening commercial aluminum alloys involves a method of solutiontreating, quenching to the aging temperature, and holding until precipitation is complete (26).

In such circumstances, the explanation offered for the improved mechanical properties is that the high equilibrium concentration of vacancies retained from the solutionizing temperature are more efficiently utilized for diffusion of solutes at the aging temperature. If the quenched aluminum alloy were allowed to remain at room temperature, the excess vacancies become annihilated and unavailable for diffusion when the alloy is reheated to the aging temperature.

However, little is known about point-defect behavior in hexagonal close-packed metals, such as Be. Still less is known about the binding energy between a solute atom such as $\mathrm{Fe}$ and a vacancy in the $\mathrm{Be}$ lattice. Whe ther or not quenched-in-excess vacancies are a significant factor in enhancing impurity diffusion rates in Be cannot as yet be determined. In this respect, of particular interest is the appearance of a 
high density. of $\mathrm{FeBe}_{11}$ with prismatic dislocation loops and helical dislocations in the brine-quenched and aged Be. Many investigators view the appearance of prismatic loops and helical dislocations in quenched metals as evidence of vacancy precipitation.

The helical dislocations are presumed to be the results of an interaction of loops with existing screw dislocations (Figure 49). This formation mechanism was observed in the present electrontransmission microscopy study (see Figure 20). But whether or not any of the quenched-in vacancies actually assisted in the precipitation of $\mathrm{FeBe}_{11}$ in the aluminum-depleted matrix is not known. There was some evidence of denuded zones of both vacancy and solute precipitates around some grain boundaries.

Scott and Lindsay (21) have made some similar studies on $\mathrm{Fe}-\mathrm{Be}$ alloys (up to 1.2-weight percent iron) which were oil-quenched and aged at temperatures of 650 to $800^{\circ} \mathrm{C}$. In contrast to the present results, precipitation of $\mathrm{FeBe}_{11}$ was noted to be difficult. In fact a 0.15weight percent $\mathrm{Fe}$ sample quenched from $920^{\circ} \mathrm{C}$ and aged at $800^{\circ} \mathrm{C}$ for times up to 120 hours showed only the beginning of precipitation at the grain boundaries. Since this $\mathrm{Fe}$ composition is approximately that of Rocky Flats ingot sheet, possibly factors other than $\mathrm{Fe}$ content contribute to the kinetics of the nucleation and growth of $\mathrm{FeBe}_{11}$ precipitates.

Scott and Lindsay (21) further found that precipitation of $\mathrm{FeBe}_{11}$ occurred much more readily upon directly annealing the as-extruded metal than the quenched material. This would suggest that plastic strain prior to the aging treatment would enhance the precipitation kinetics in their material. The Russians have initiated some work on prestressing Be single crystals at $400^{\circ} \mathrm{C}$ to obtain an increase in yield point and greater plastic deformation (28). They postulate that this change is a result of the redistribution of solute impurities from the prismatic to the basal planes, thereby permitting dislocation to utilize the prism planes for movement. It is also interesting to note that dislocations were often associated with the $\mathrm{FeBe}_{11}$ platelets observed in this study (see Figure 29). These dislocations could have been: (a) misfit interfacial dislocations which occur at a precipitate interface to reduce the lattice strain (27), or (b) intruder dislocations from the matrix which have been captured by the precipitate particle.
All of the investigations point to the need for a better understanding of the behavior of lattice defects. in Be, particularly point defects such as solute atoms, vacancies, and interstitials, since these apparently play a prominant and fundamental role in determining the precipitation behavior of commercial purity beryllium.

\section{CONCLUSIONS}

A variety of heat-treatments which effect the precipitate characteristics of Rocky Flats Be ingot oheet have beell investlgated by electron-transmission microscopy. The study shows that the precipitation reaction involves a reversible roaction between the ternary, $\mathrm{AMBB}_{4}$ and free aluminum or aluminum-rich precipitation at the grain boundaries. Thus aging of the as-rolled $\mathrm{Be}$ ingot sheet at $780^{\circ} \mathrm{C}$ produces round and irregular-shaped $\mathrm{AlMBe}_{4}$ precipitates in the structure. The ternary compound dissolves on heating above $900^{\circ} \mathrm{C}$ leaving free aluminum at the recrystallized grain boundaries.

The reaction essentially follows that of Equation 2 (see Page 8), although the temperatires for Rocky Flats ingot sheet are about 875 to $900^{\circ} \mathrm{C}$ for the reaction to the right and below $800^{\circ} \mathrm{C}$ for the reaction to the left.

However, if the ingot sheet is cooled rapidly enough from above $900^{\circ} \mathrm{C}$ to prevent solute diffusion and the attainment of equilibrium; subsequent aging will produce $M \mathrm{Me}_{11}$ platelets in the aluminum depleted matrix. Both the $\mathrm{AlMBe}_{4}$ and the $\mathrm{MBe}_{11}$ precipitates will dissolve after resolutionizing above $900^{\circ} \mathrm{C}$. These precipitation reactions for Rocky Flats Be ingot sheet can be summarized graphically as noted in Equation 3 (see Page 8).

\section{REFERENCES}

1. L. M. Schetky and H. A. Johns on, Editors. Beryllium Technology. Volume 1. Gordon and Breach, Science Publishers, New York. 1966.

2. A. W. Jones and R. T. Weiner. Journal of LessCommon Metals, 6:266-282. 1964. 
3. A. Moore. Journal of Nuclear Metals, 3:113-114. 1961 .

4. H. P. Rooksby. Journal of Nuclear Metals, 7:205-211. 1962

5. J. A. Carrabine, et al. Journal of Nuclear Metals, 8:278-280. 1963.

6. R. J. Teitel and M. Cohen. Transactions of the American Institute of Metallurgical Engineers, 18:285. 1949.

7. A. Moore and W. B. H. Lord. The Development of Beryllium for Use in Aircraft. Fifth Metallwork Plansee Proceedings, Austria. June 1964.

8. R: N. Katz and J. Greenspan. Acta Metallurgica, 14:1124-1126. 1966.

9. H. H. Hausner. Beryllium, Its Metallurgy and Properties. University of California, Berkeley, California. 1965.

10. G. E. Darwin and J. H. Buddery. Beryllium. Butterw orths Publications Limited, London, England. 1960.

11. G. V. T. Ranzetta and V. D. Scott. Journal of Nuclear Metals, 10:113-126. 1963.

12. I. G. D’Yakov, et al. Fizika Metallov i Metal.lovedenie, 21:785-786. 1966.

13. V. K. Grotzky and F. J. Fraikor. Journal of Les.s Conmmon Metals, 14:244-246. 1968.

14. J. Moriceau, et al. Beryllium Research and Development Program: Influence of the Distribution of Oxide and of the Total Impurity Level on Recrystallization and Grain Growth of Beryllium. Report No. ASD-TDR-62-509. Volume VI. Pcchincy Company, Chambery, France.

February 1965.

15. V. R. Friebel. Metallography of Wrought VacuumCast Beryllium at Elevated Temperatures. RFP-544.
Rocky Flats Division, The Dow Chemical Company, Golden, Colorado. November 22, 1965.

16. D. W. White and J. E. Burke, Editors. The Metal Beryllium. American Society for Metals, Cleveland, Ohio. 1955. Pages 466-504.

17. V. D. Scott and H. M. Lindsay. Journal of Nuclear Metals, 18:176-186. 1966.

18. S. Gelles, et al. Journal of Metals, November 1963. Pages $1-6$.

19. F. J. Fraikor and V. K. Grotzky. Transactions of the American Institute of Metallurgical Engineers, Volume 239. December 1967. Page 2008.

20. P. Pointu, et al. Comptes Rendus, 256:44194421. 1963.

21. V. D. Scott and H. M. Lindsay. Journal of Nuclear Metals, 18:145-177. 1966.

22. J. A. Carrabine, et al. Journal of Nuclear Metals, 8:239-257. 1949.

23. J. E. Meredith and J. Sawkill. Proceedings on the Metallurgy of Beryllium. Chapman and Hall Limited, London, England. 1963. Pages 137-419.

24. Y: Adda, et al. Cumm Aux Journees Metallurgiques D'Automne. 1963.

25. H. D. Hanes, et al. Physical Metallurgy of Beryllium, DMIC Report No. 230. Battelle Memorial Institute, Columbus, Ohio. June 24, 1966.

26. J. Katz. Metal Progress, 70-72. 1966.

27. V. A. Phillips. Acta Metallurgica, 271-277. 1966.

28. I. A. Gindin, et al. Fizika Metallov i Metal: lovedenie, $21: 774-778.1966$.

29. M. I. Jacobson. Transactions of the American Society for Metals Quarterly, 57:482-493. 1964. 
RFP-104I

\section{ILLUSTRATIONS}




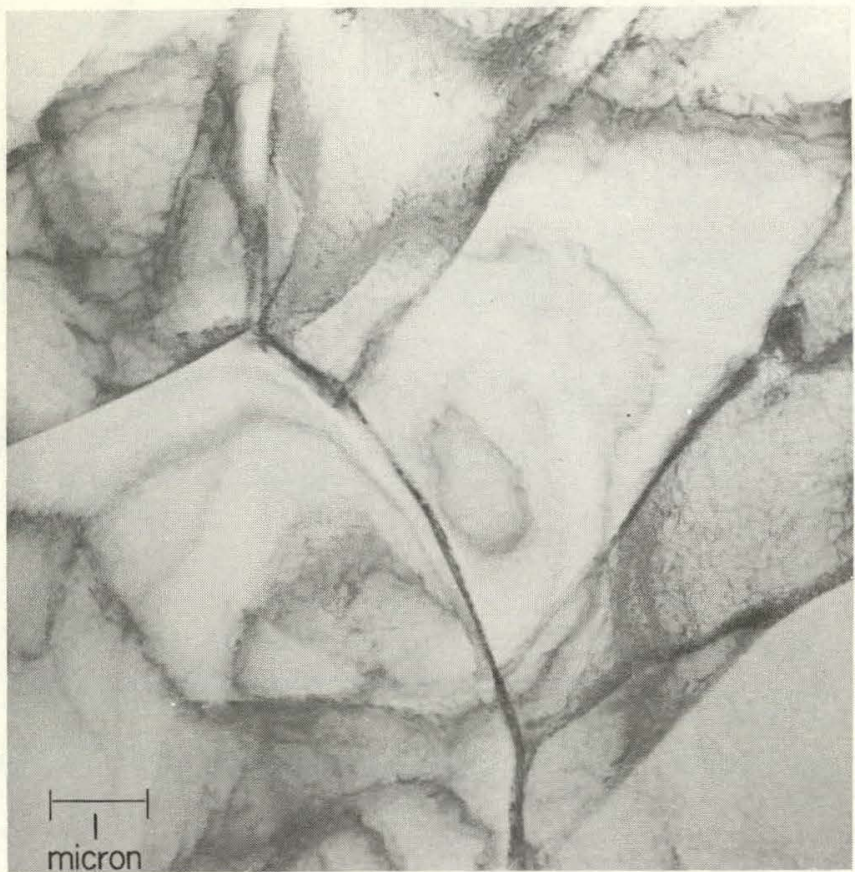

FIGURE 1. Dislocation subgrains in the as-rolled beryllium ingot sheet (Billet No. 501174-A). The plane of the foil is the rolling plane of the beryllium sheet. Markers indicate one micron in length $(10,000$ angstroms).

FIGURE 3. Optical photomicrograph of the as-rolled, warm-worked substructure of a 0.225 -inch beryllium ingot sheet. Dark spots are etch pits. Other areas show evidence of partial recrystallization (bright field, magnification, 250X).

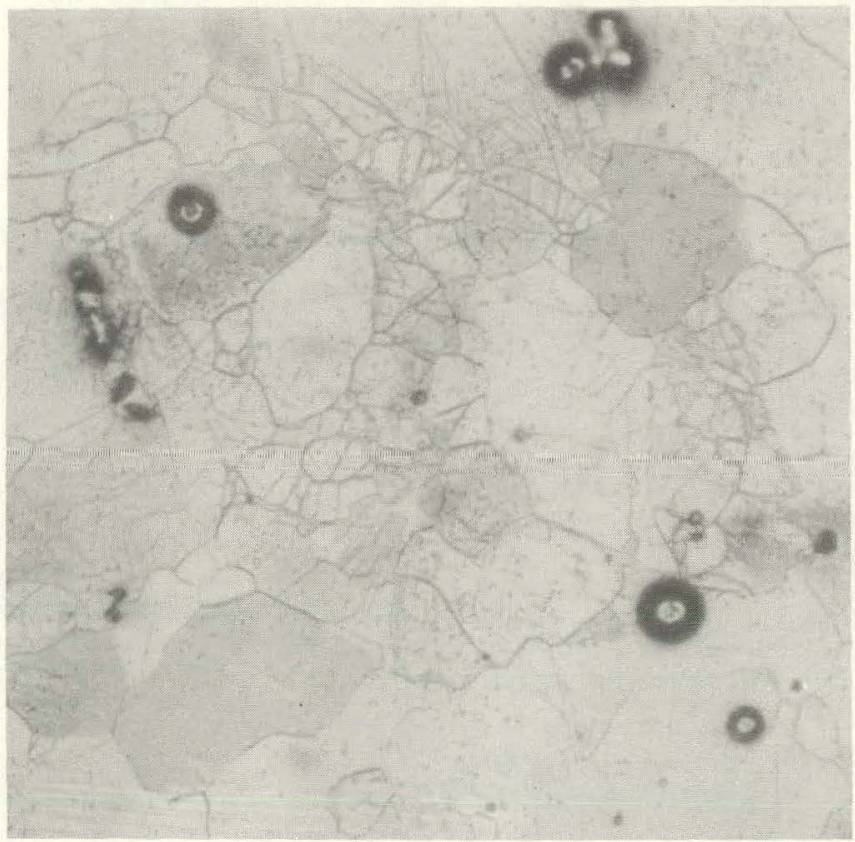

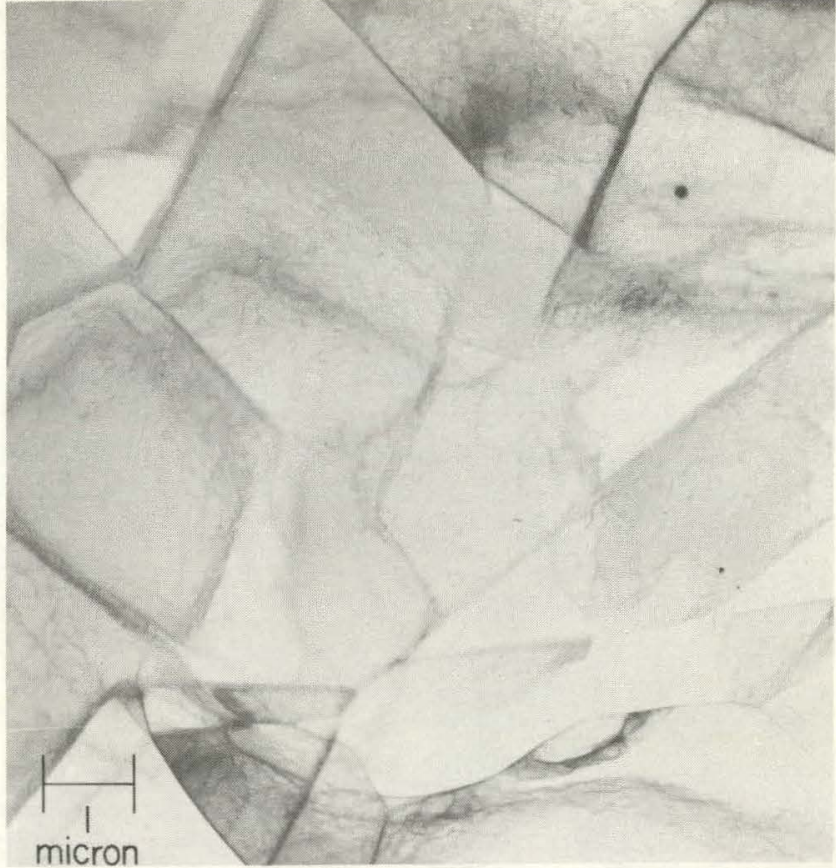

FIGURE 2. Photomicrograph of beryllium ingot sheet (Billet No. 8-92-2) in the as-rolled condition. The subgrains are approximately 1 to 5 microns in diameter.

FIGURE 4. A higher magnification view of the foil seen in Figure 2. Note the boundary fringe at (a). Marker indicates 0.5 microns in length (5000 angstroms).

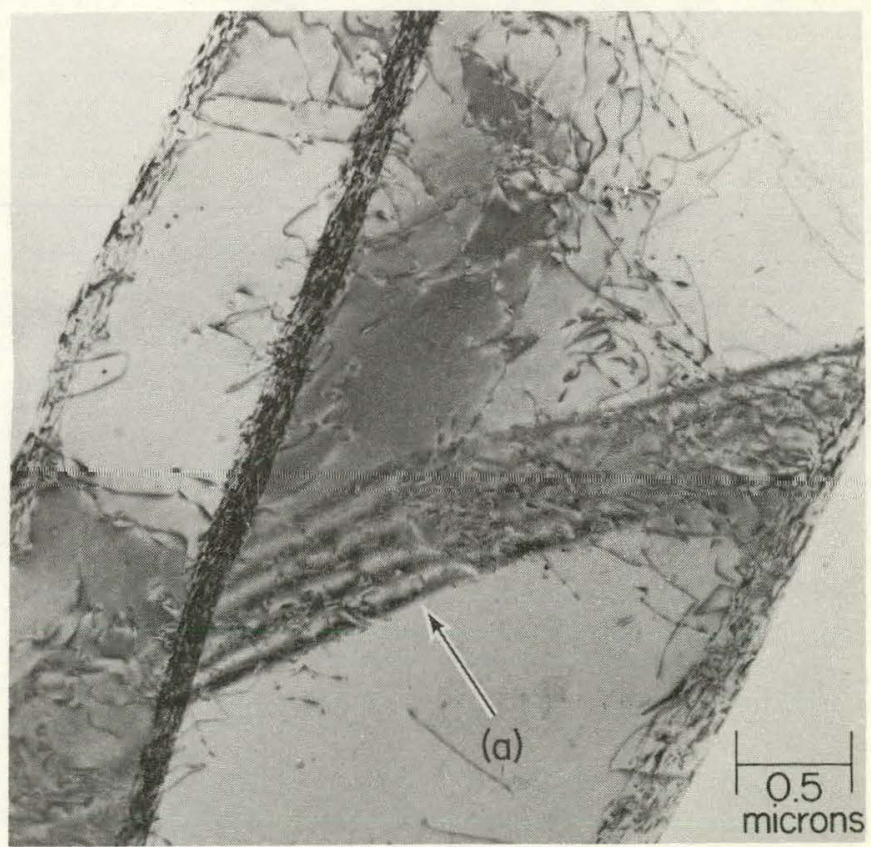




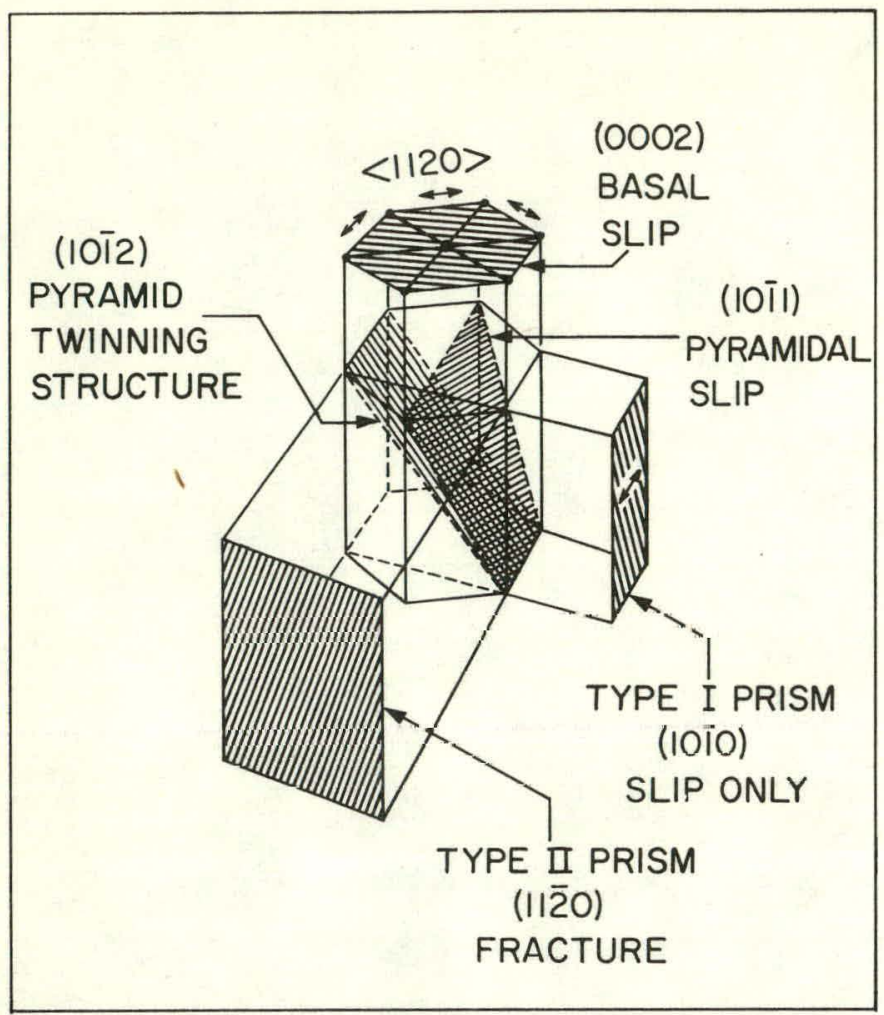

S. Gelles (Reference 18)

FIGURE 5. Crystallographic directions and planes in hexagonal close-packed beryllium.

FIGURE 7. Globular precipitates associated with dislocation arrays in the subboundaries of as-rolled beryllium ingot foil.

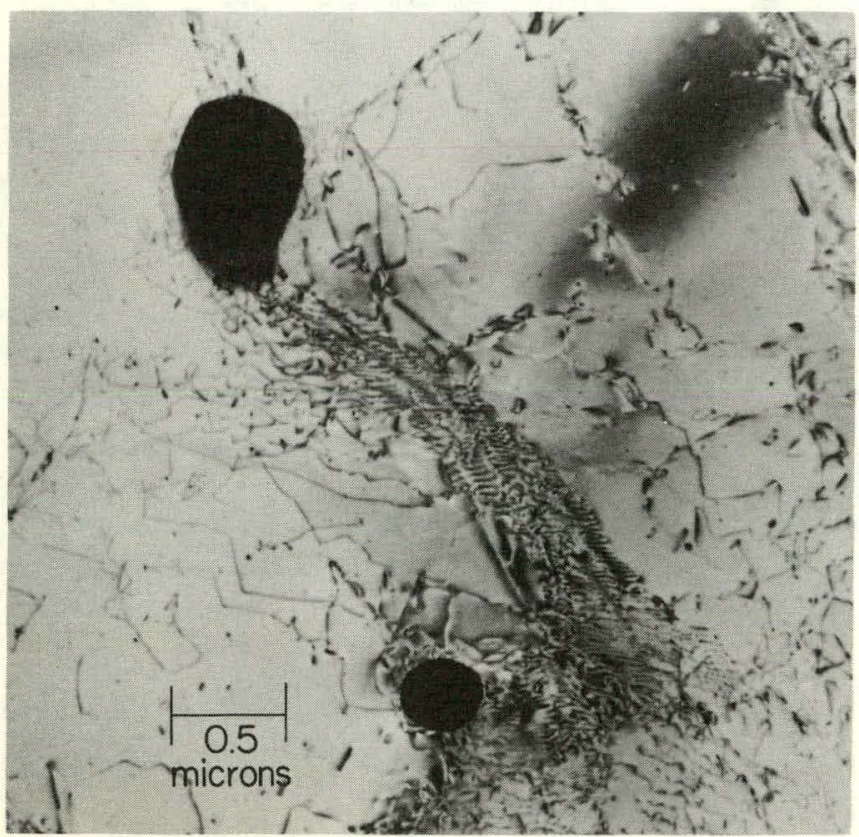

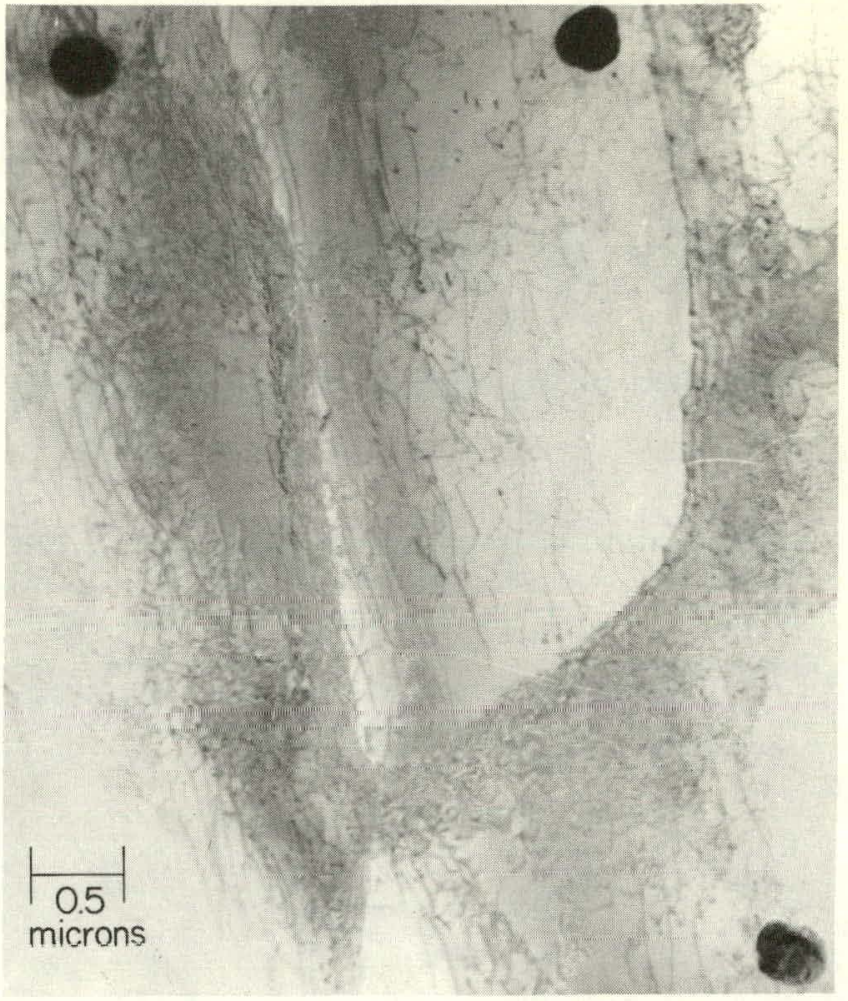

FIGURE 6. Precipitates (type $\mathrm{AlFeBe}_{4}$ ) in the as-rolled beryllium foil.

FIGURE 8. Optical photomicrograph of Billet No. $176 \mathrm{CN}$, a 0.225 -inch beryllium sheet heated at $780^{\circ} \mathrm{C}$ for a half hour. Little change is noted compared with the as-rolled microstructure in Figure 3 (bright field, magnification 250X).

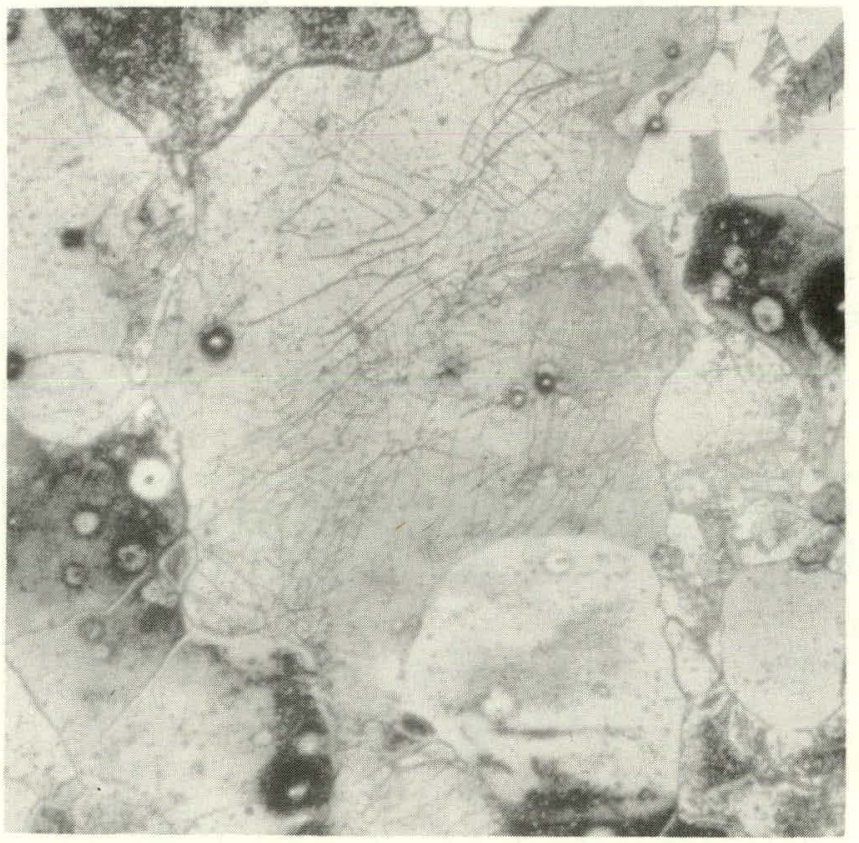




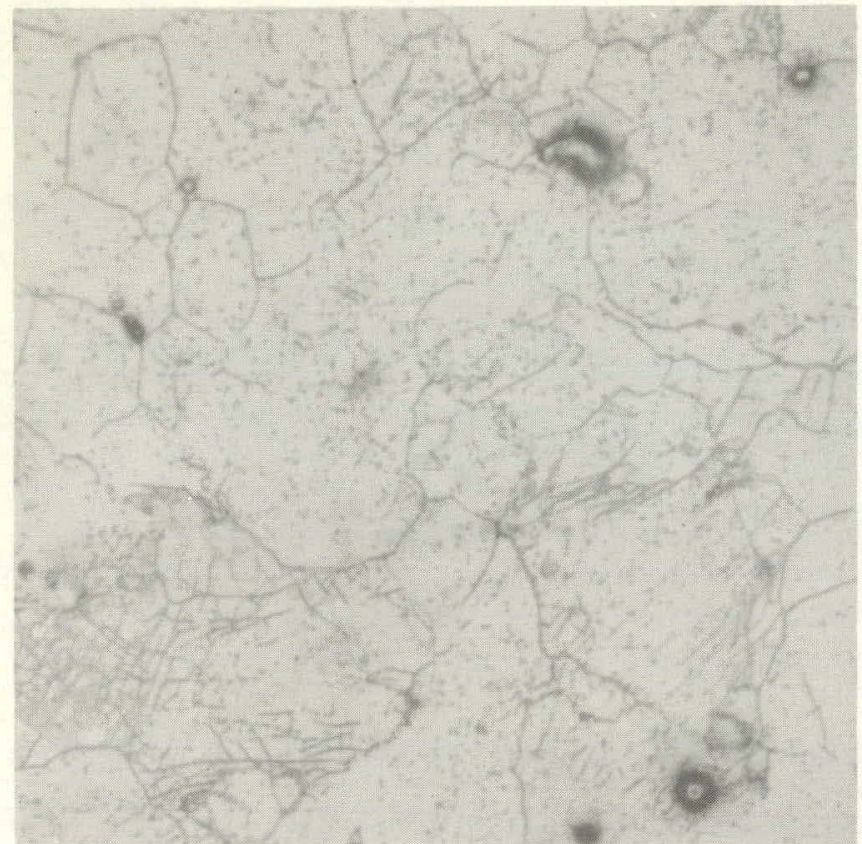

FIGURE 9. Microstructure of a 0.255-inch beryllium ingot sheet heated at $780^{\circ} \mathrm{C}$ for one hour (bright field, magnification 250X).

FIGURE 11. Beryllium ingot sheet heated at $780^{\circ} \mathrm{C}$ for 20 hours (bright field, magnification $250 \mathrm{X}$ ).

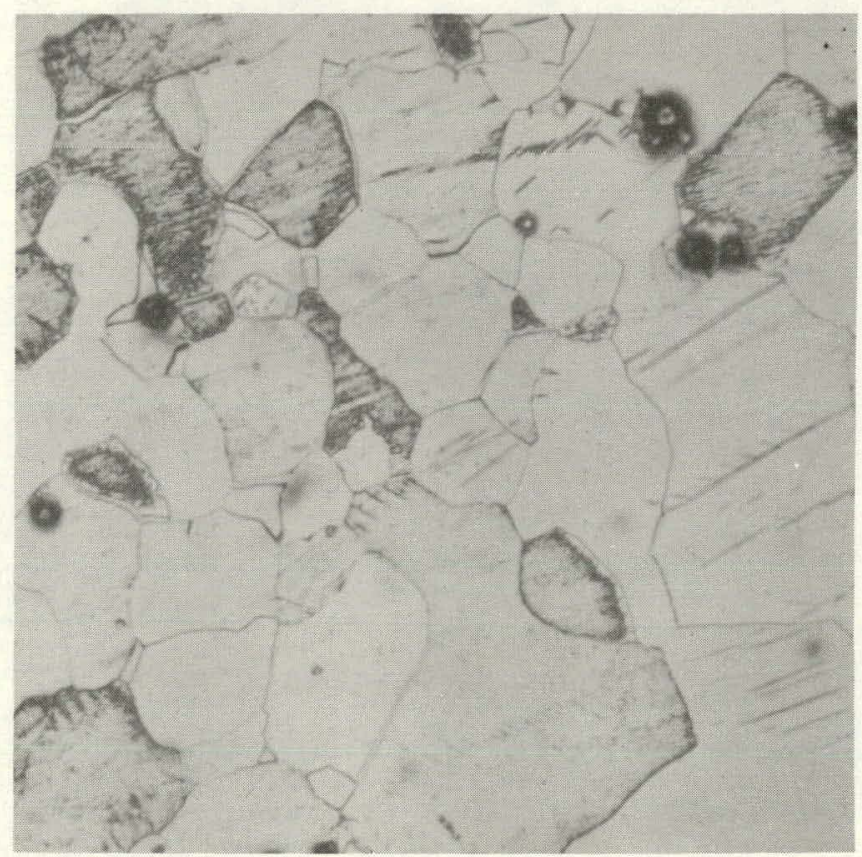

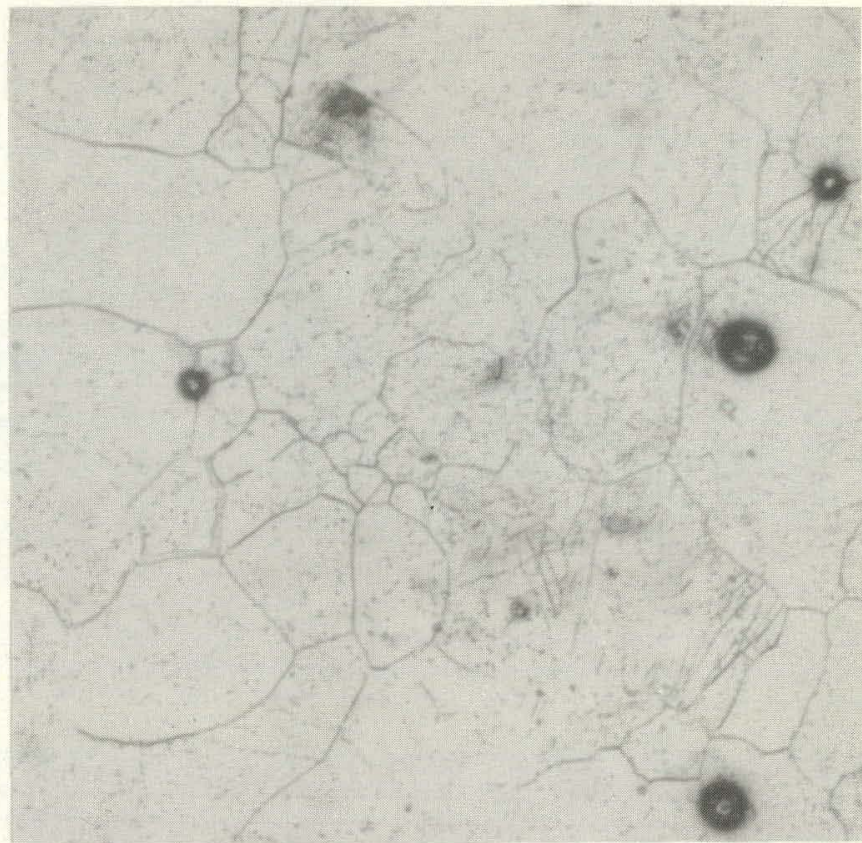

FIGURE 10. Optical photomicrograph of a 0.255 inch beryllium ingot sheet heated at $780^{\circ} \mathrm{C}$ for two hours. Some evidence is seen of a few remaining subboundaries (bright field, magnification 250X).

FIGURE 12. Precipitates (black spots) in the subboundaries of beryllium ingot sheet, aged for one hour at $780^{\circ} \mathrm{C}$. The white spots are etch holes and thin areas.

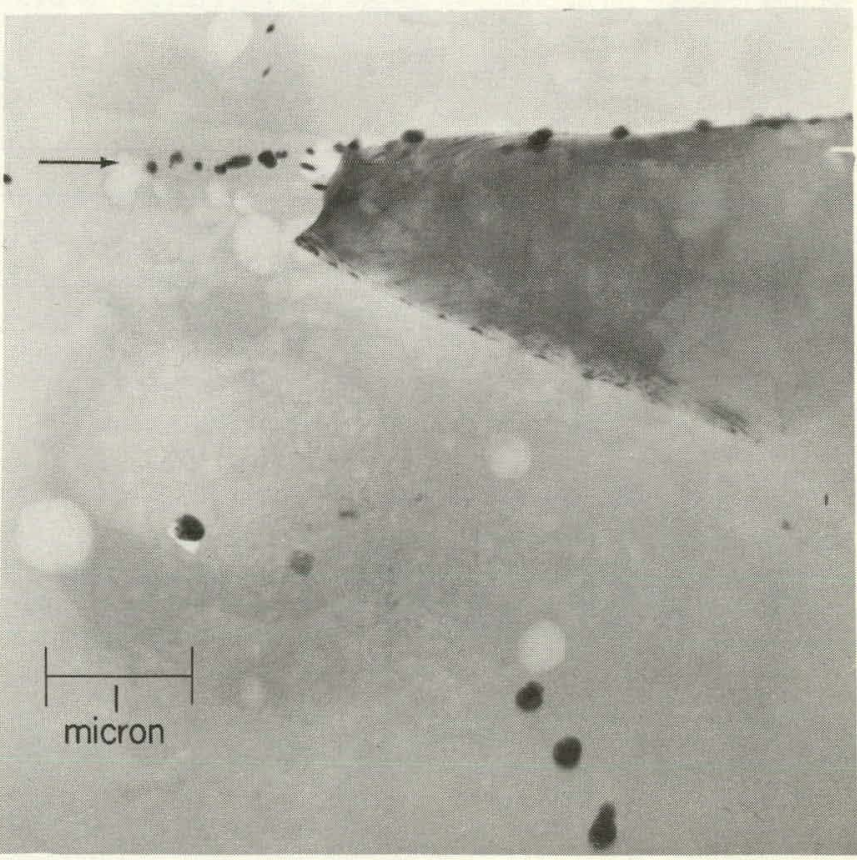




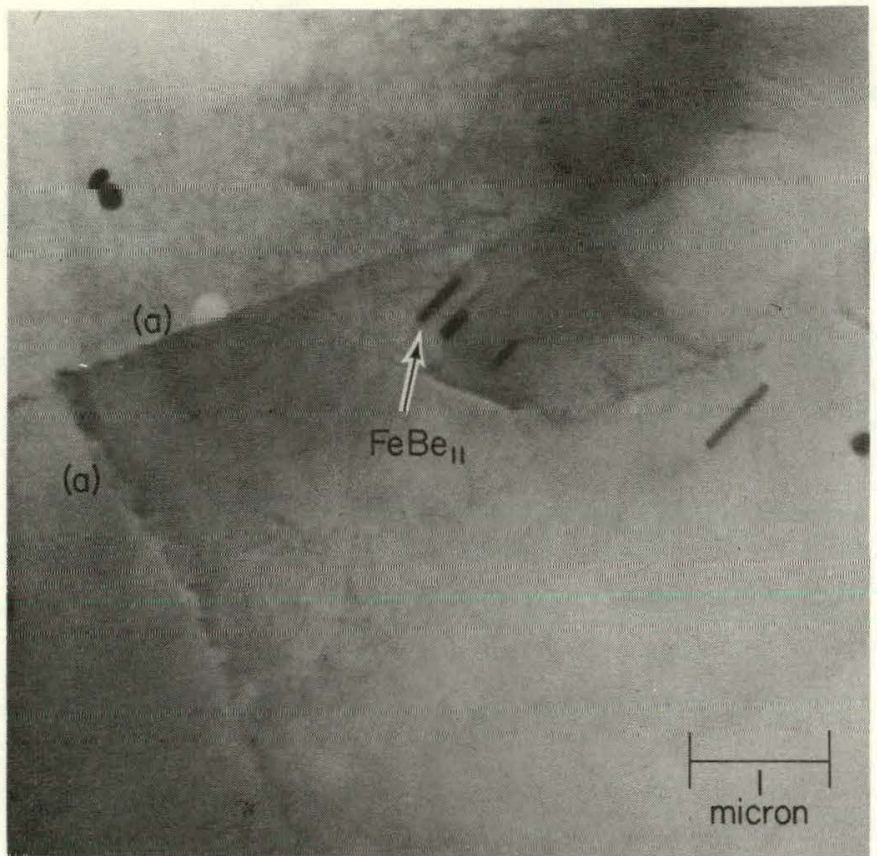

FIGURE 13. Precipitates ( $\mathrm{FeBe}_{11}$ platelets) in beryllium ingot sheet, aged for one hour at $780^{\circ} \mathrm{C}$. Note the subboundaries at (a).

FIGURE 15. Another row of precipitates (both $\mathrm{AlFeBe} e_{4}$ and $\mathrm{FeBe}_{11}$ ) in the matrix of a beryllium specimen, aged at $780^{\circ} \mathrm{C}$ for six hours. The dislocations are generally out of contrast except at the extinction contour (a).

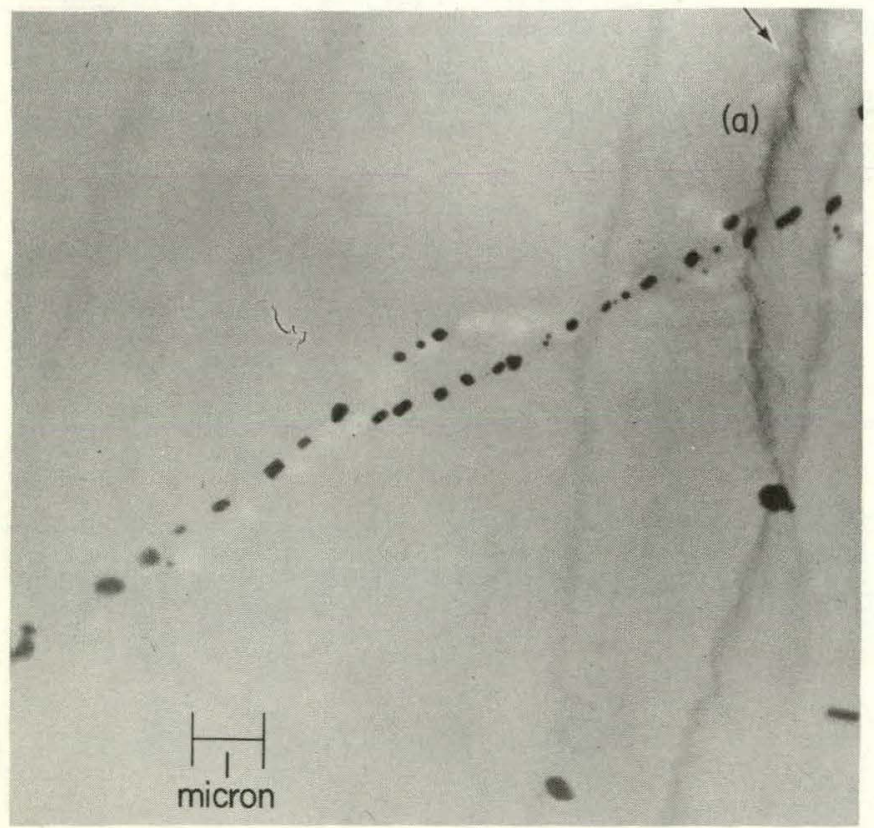

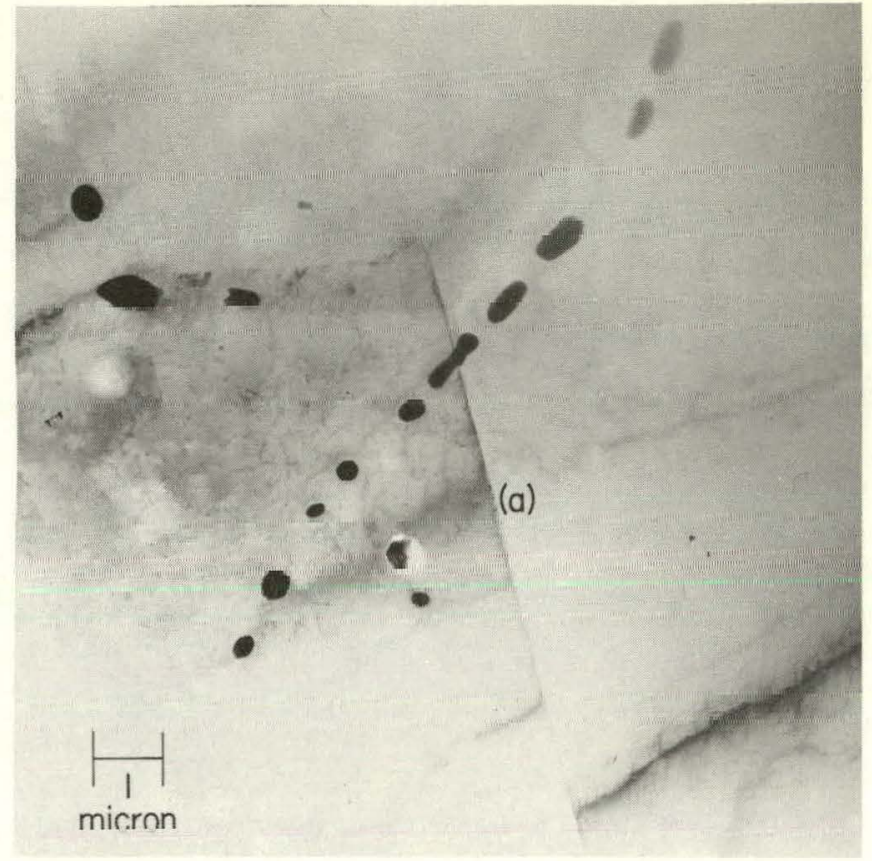

FIGURE 14. A row of precipitates in beryllium ingot sheet (Billet No. $176 \mathrm{CN}, 0.225$ inches), aged at $780^{\circ} \mathrm{C}$ for six hours. Note the grain boundary at (a). The dislocations within the matrix were probably introduced during the thinning and handling operations.

FIGURE 16. Precipitate particle (arrow) inhibiting grain-boundary migration in beryllium ingot sheet, aged for 16 hours at $780^{\circ} \mathrm{C}$.

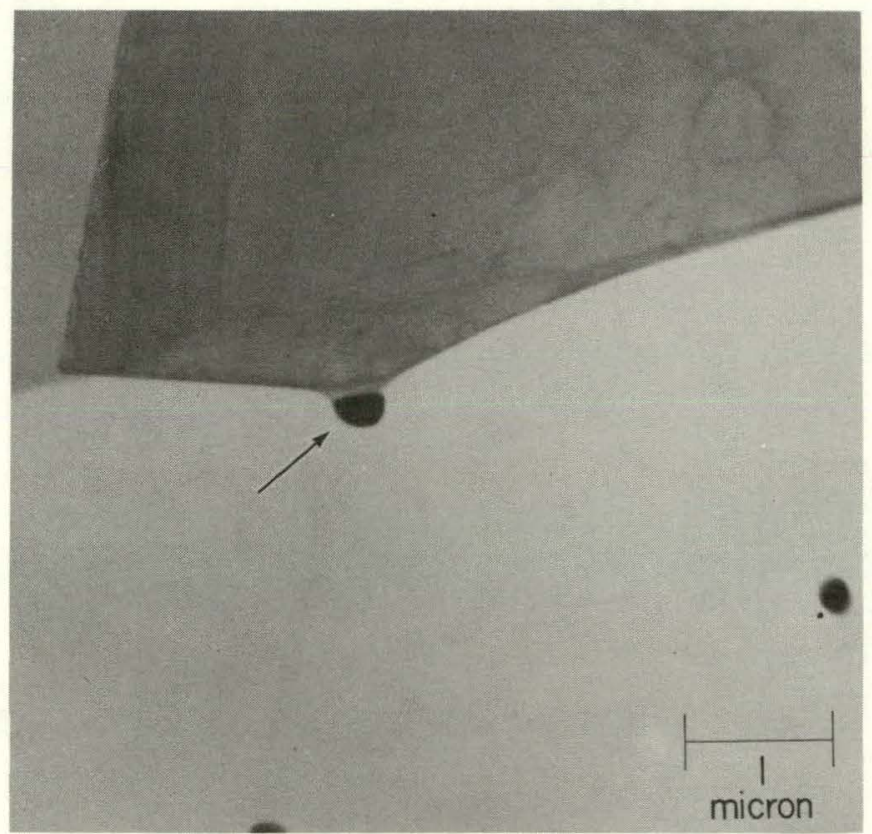




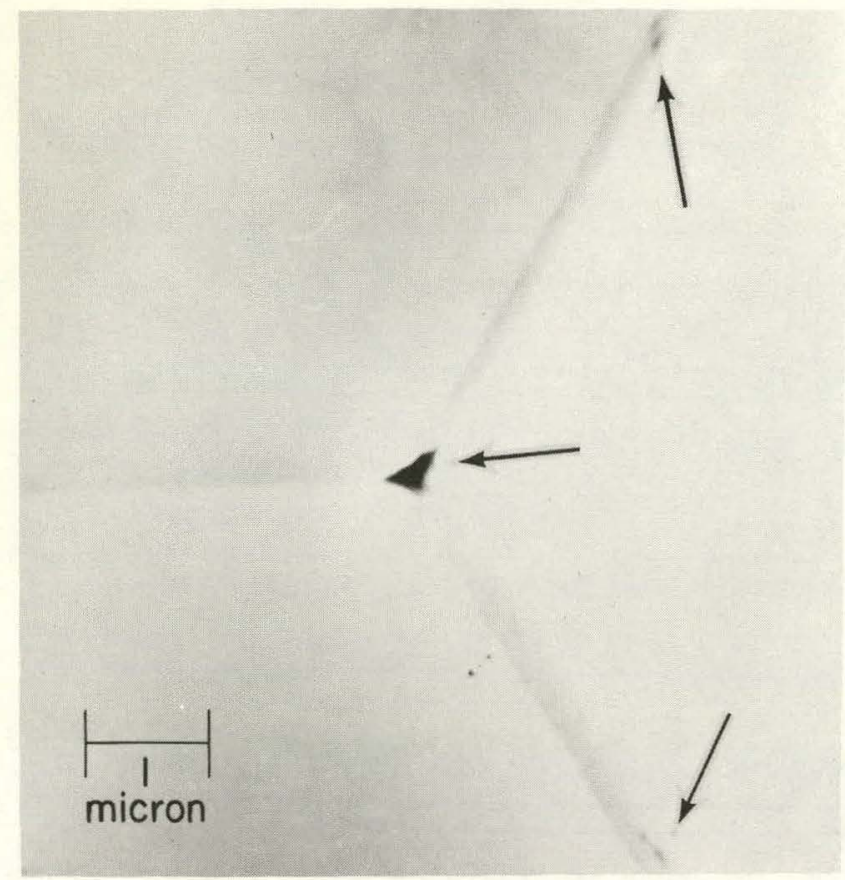

FIGURE 17. Small, aluminum-rich precipitates (arrows) in grain boundary and grain-boundary intersection of an ingot sheet sample quenched from $1200^{\circ} \mathrm{C}$ into brine at $-7^{\circ} \mathrm{C}$.

FIGURE 19. Prismatic dislocation loops $1 / 3\langle 11 \overline{2} 0\rangle$ in beryllium ingot sheet, quenched from $1100^{\circ} \mathrm{C}$ into brine at $-8^{\circ} \mathrm{C}$ and annealed at room temperature. Note the interactions between two loops at the areas marked (a).

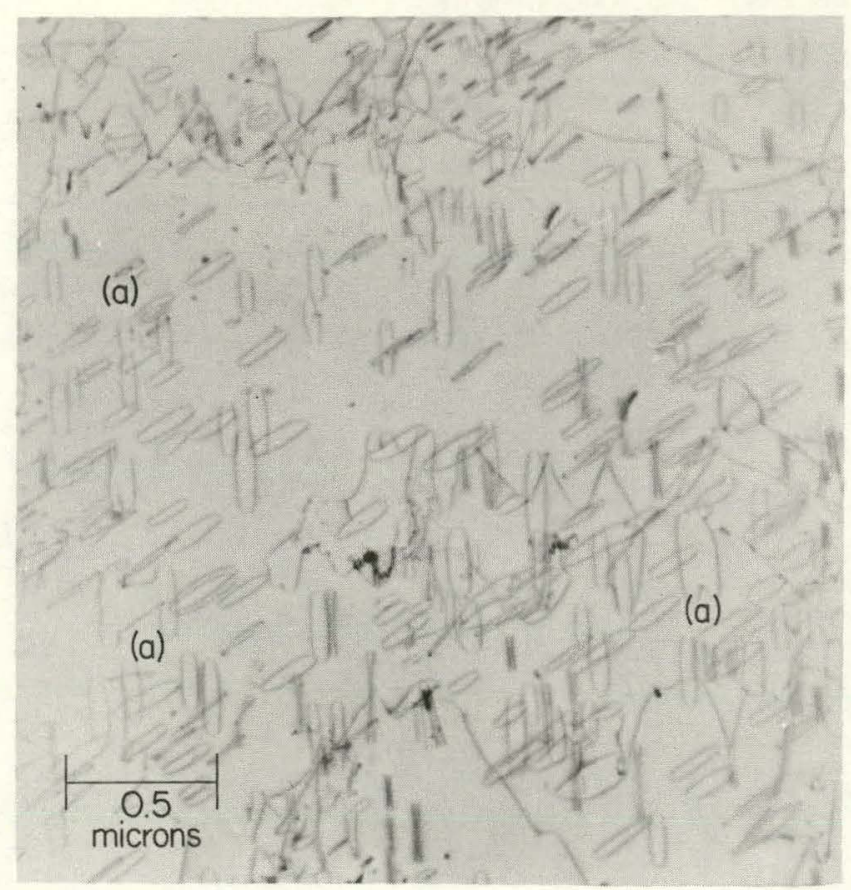

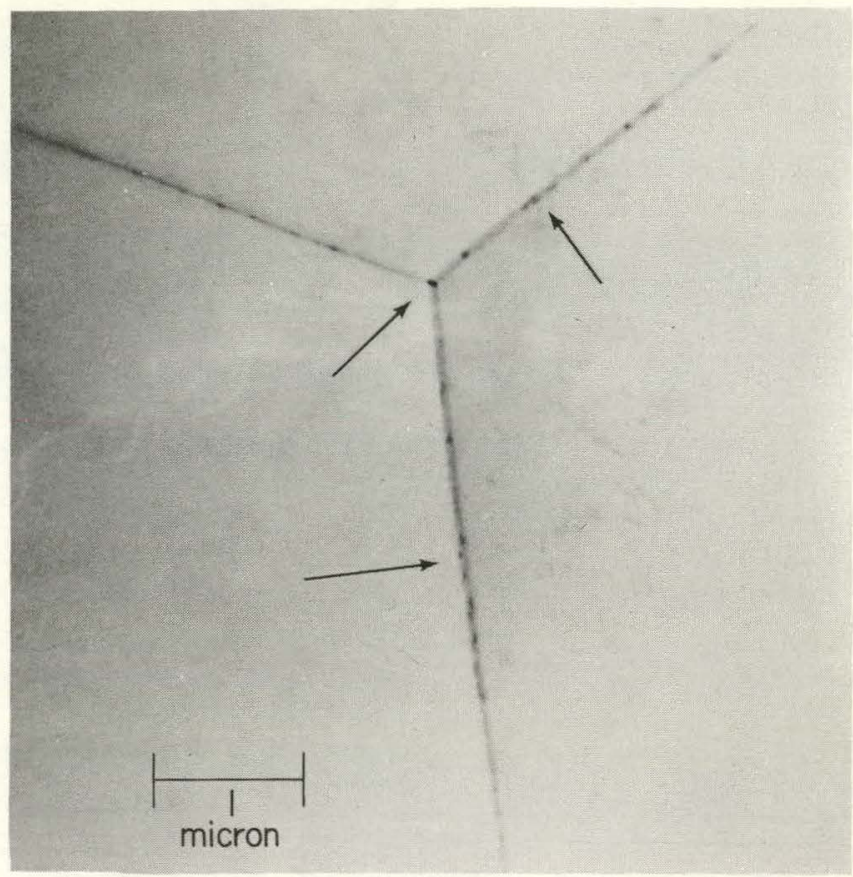

FIGURE 18. Grain-boundary precipitates (arrows) in highpurity beryllium ingot foil ( 0.005 inches thick), supplied by the Beryllium Corporation (quench temperature, $1175^{\circ} \mathrm{C}$ ).

FIGURE 20. Prismatic loops $1 / 3\langle 11 \overline{2} 0\rangle$ in the same foil shown in Figure 19, but at a higher magnification. Note the cross slip of a loop to an adjacent glide plane at (a) and the interaction of loops with the screw dislocation at (b) to form a helical dislocation.

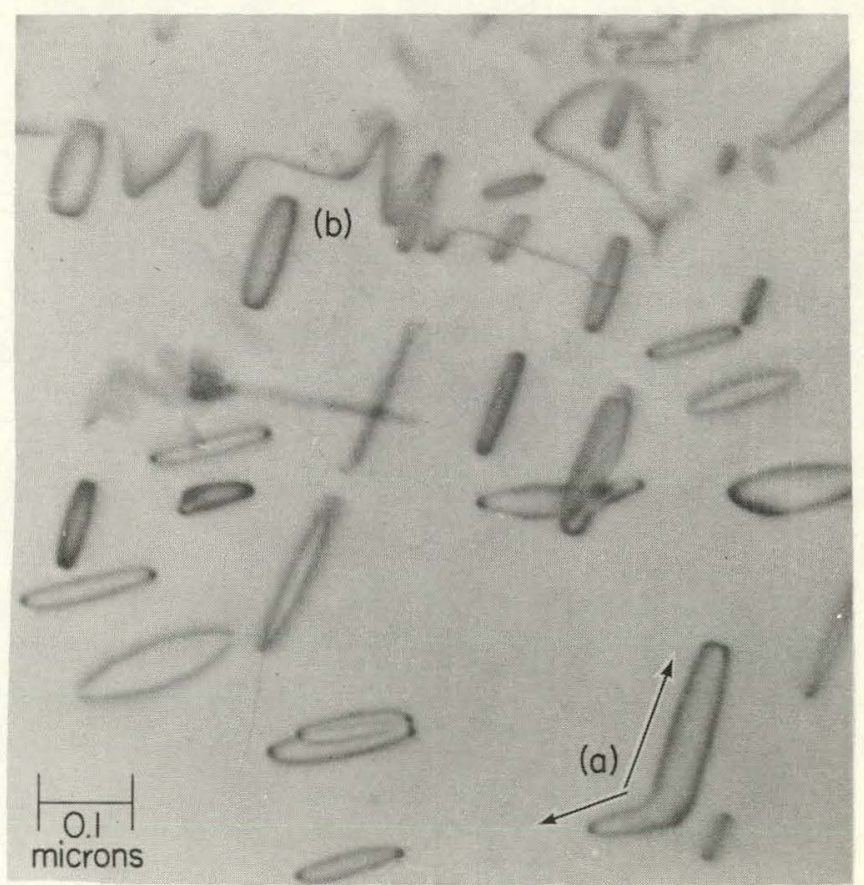




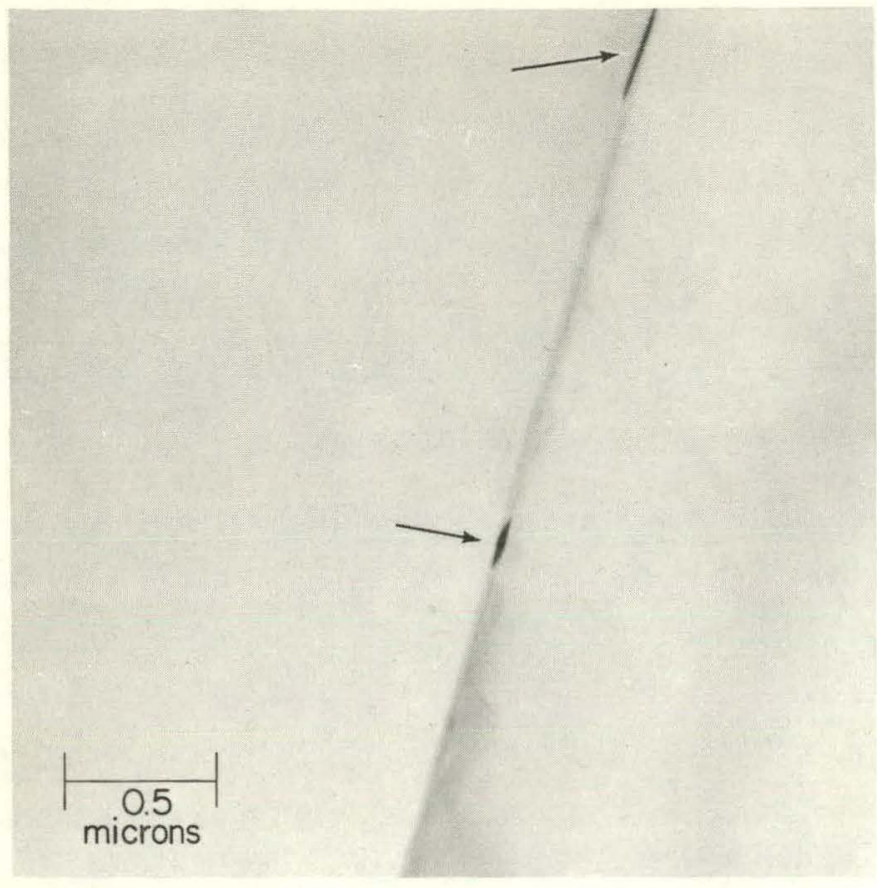

FIGURE 21. Grain-boundary precipitates (arrows) in a 0.003-inch thick beryllium ingot foil, argoncooled from $1000^{\circ} \mathrm{C}$ in the end of the furnace tube.

FIGURE 23. Lenticular-shaped, grain-boundary precipitates in a beryllium ingot foil furnace-cooled from $1000^{\circ} \mathrm{C}$ (as in Figure 22), and subsequently reheated to $1000^{\circ} \mathrm{C}$ for 15 minutes and brine-quenched.

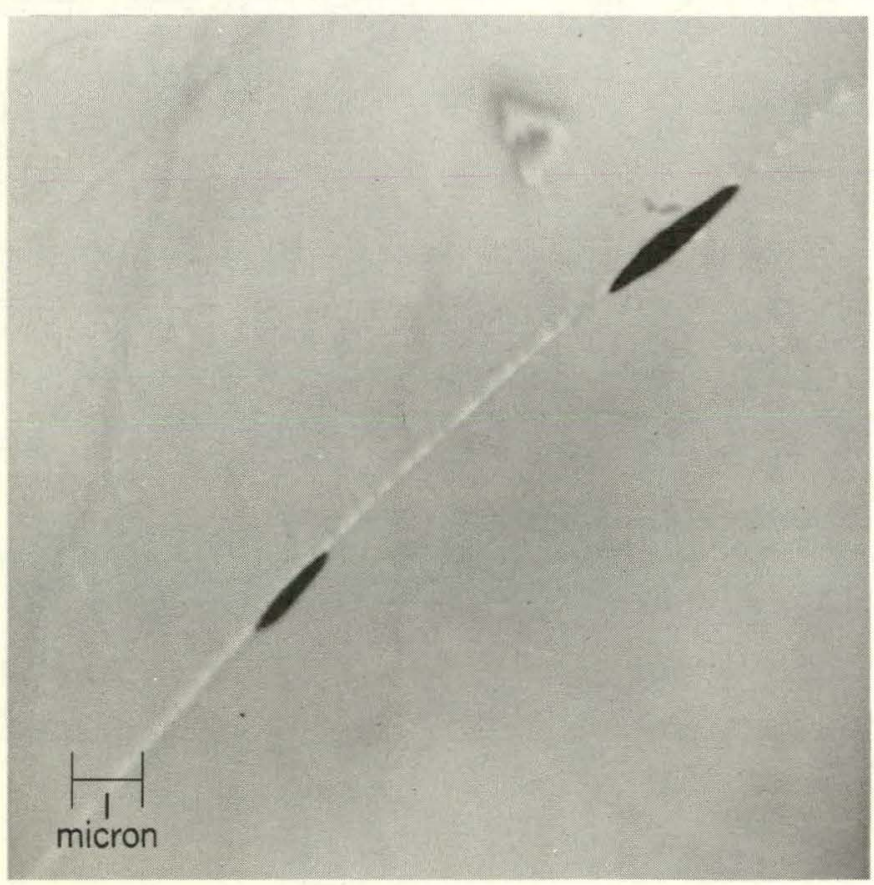

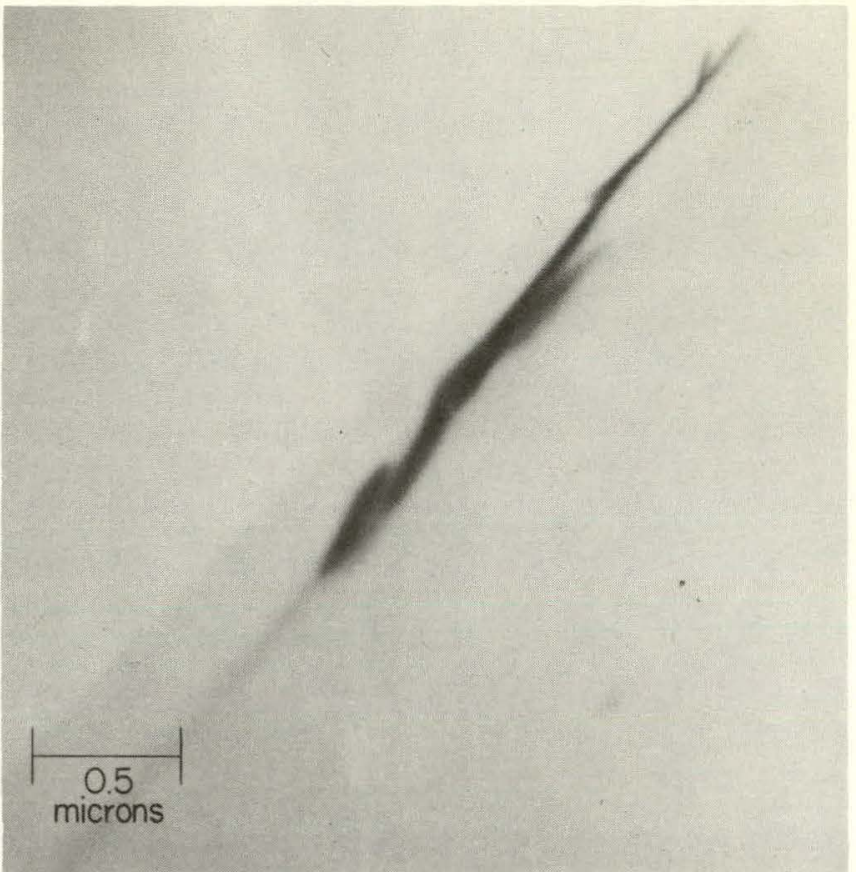

FIGURE 22, Precipitate ( $\mathrm{AlFeBe}_{4}$ type) in the grain boundary of beryllium ingot foil furnace-cooled from $1000^{\circ} \mathrm{C}$. Contrast these with the fine, lenticular aluminum-rich precipitates in the Figures 25 and 26 .

FIGURE 24. Grain size (about 175 microns) in beryllium ingot sheet held at $1000^{\circ} \mathrm{C}$ for 15 minutes and brine-quenched. The dark spots are merely etch pits (bright field, magnification $75 \mathrm{X}$ ).

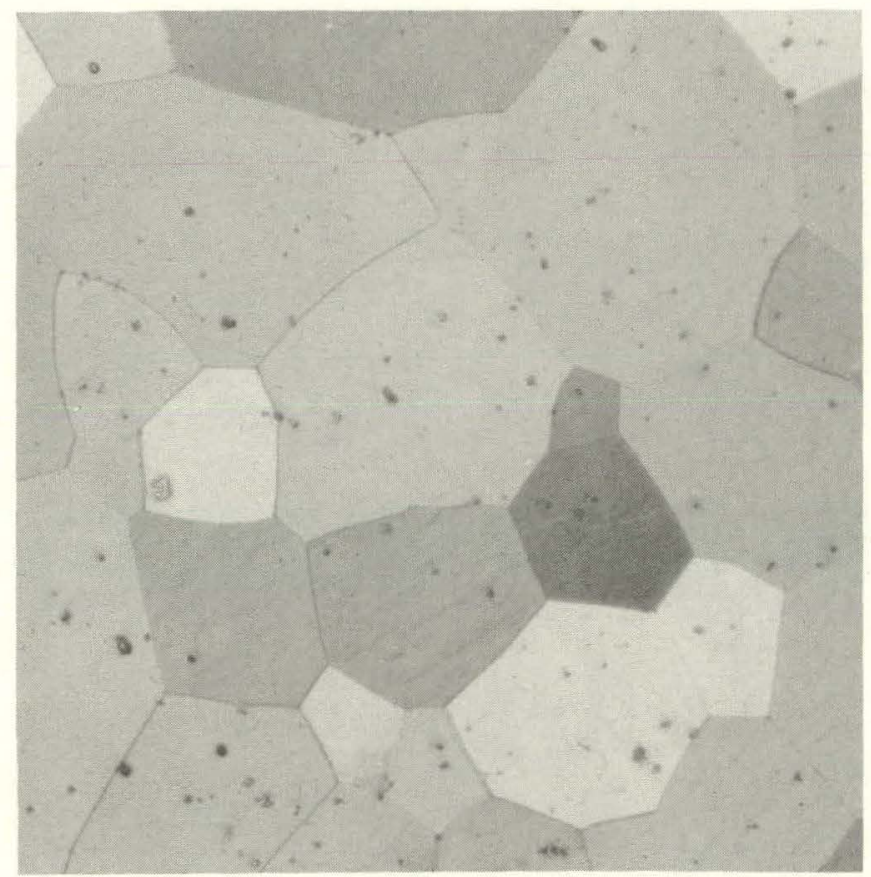




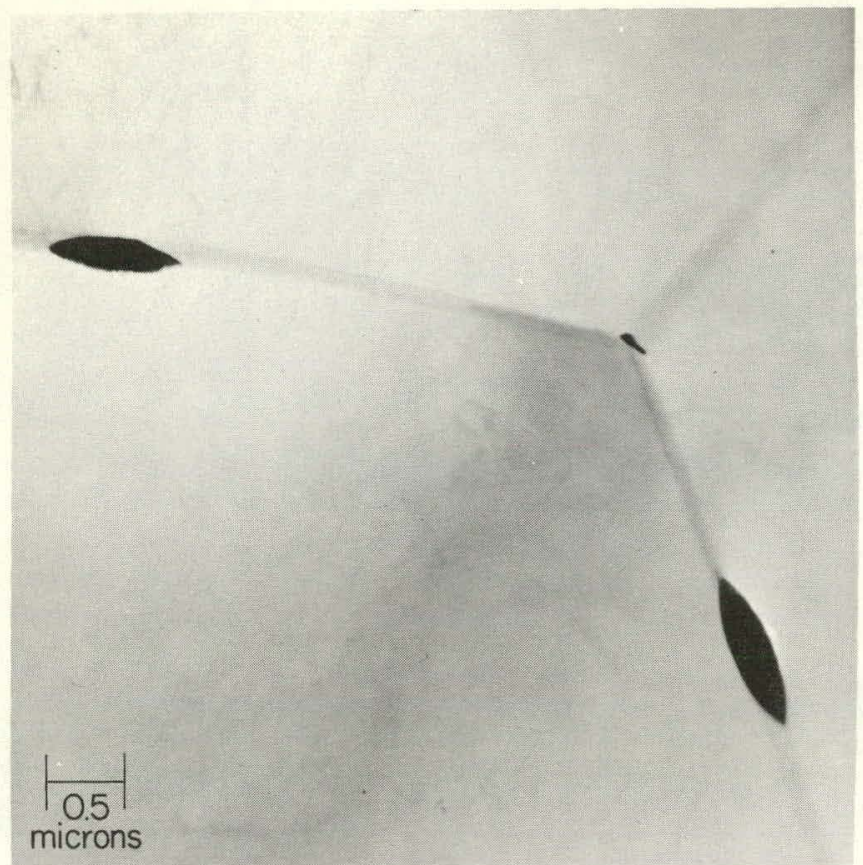

FIGURE 25. Lenticular-shaped, aluminum-rich precipitates in the grain boundaries of beryllium ingot sheet brine-quenched from $1000^{\circ} \mathrm{C}$, and aged at $780^{\circ} \mathrm{C}$ for only one minute. The dislocations have been tilted out of contrast in a search for matrix precipitates, but none were found at the initial short-aging time.

FIGURE 27. Platelets of $\mathrm{FeBe}_{11}$ in the matrix of a beryllium specimen, brine-quenched from $1000^{\circ} \mathrm{C}$ and aged at $780^{\circ} \mathrm{C}$ for one hour. Some of the platelets are viewed at (a) and others have the face almost parallel to the foil surface (b). Dislocations are tilted out of contrast.

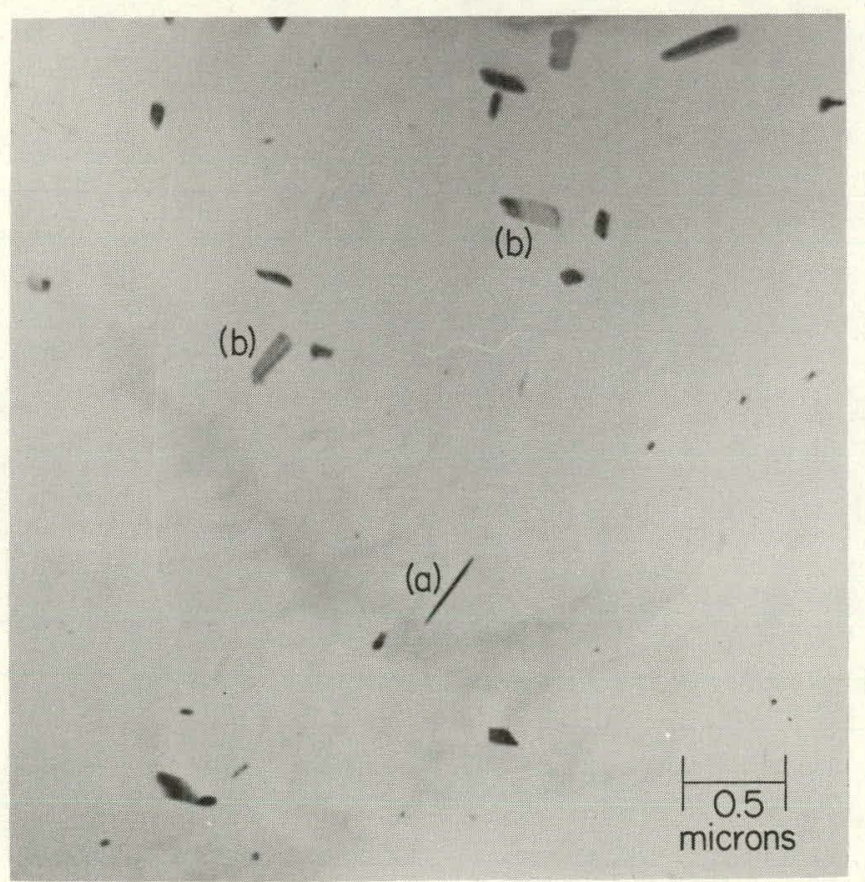

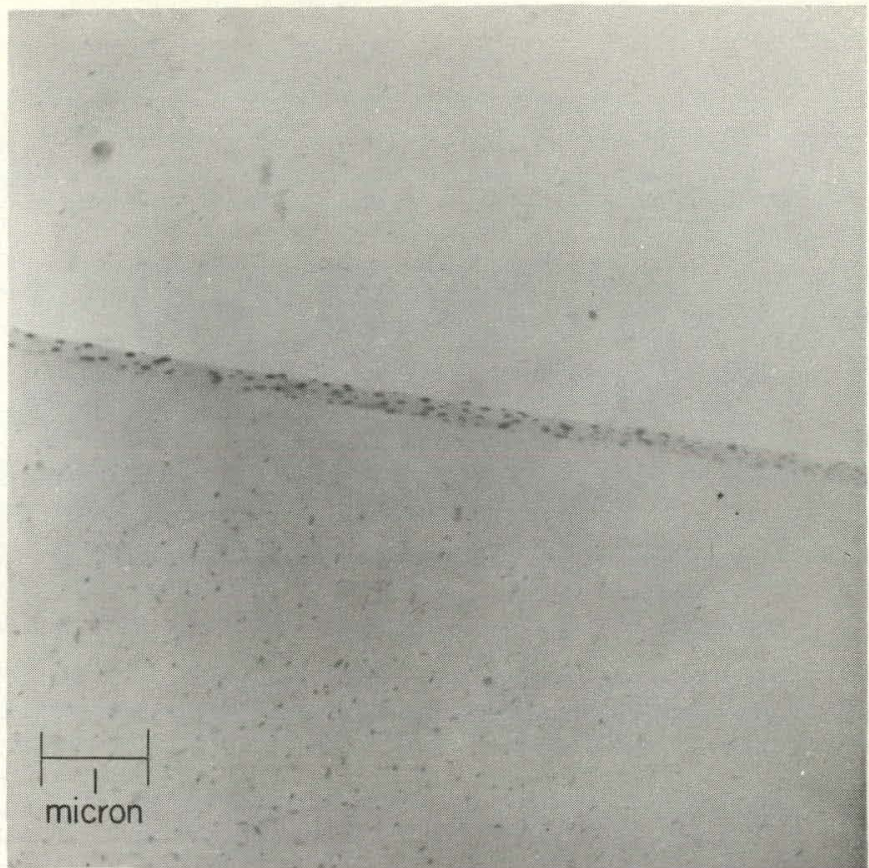

FIGURE 26. Grain-boundary and matrix precipitates in a beryllium sample brine-quenched from $1000^{\circ} \mathrm{C}$ and aged to $780^{\circ} \mathrm{C}$ for five minutes. In contrast to Figure 25, matrix precipitates are definitely in evidence.

FIGURE 28. Platelets $\left(\mathrm{FeBe}_{11}\right) \frac{1}{3}\langle 11 \overline{2} 0\rangle$ prismatic dislocation loops in brine-quenched and aged beryllium ingot sheet; quenching temperature, $1000^{\circ} \mathrm{C}$ and annealing temperature, $780^{\circ} \mathrm{C}$ for one hour. Note the cross slip of opposite ends (opposite line direction) of the prismatic loop at (a). Note also the bowout of dislocations at boundary and platelets (arrows).

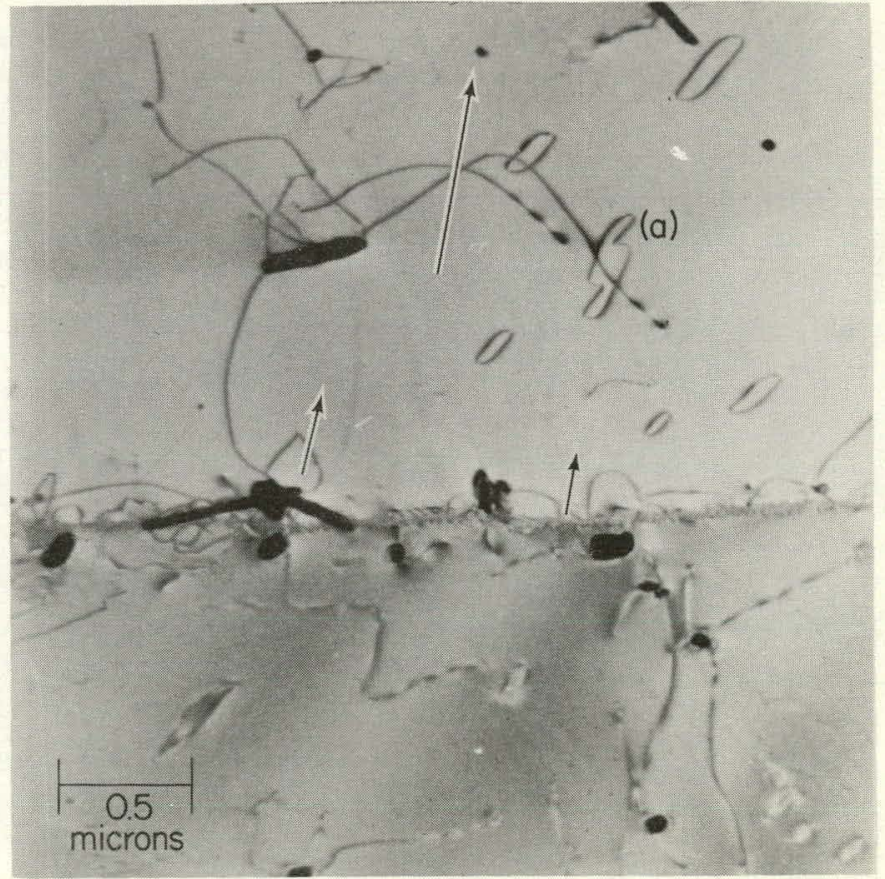




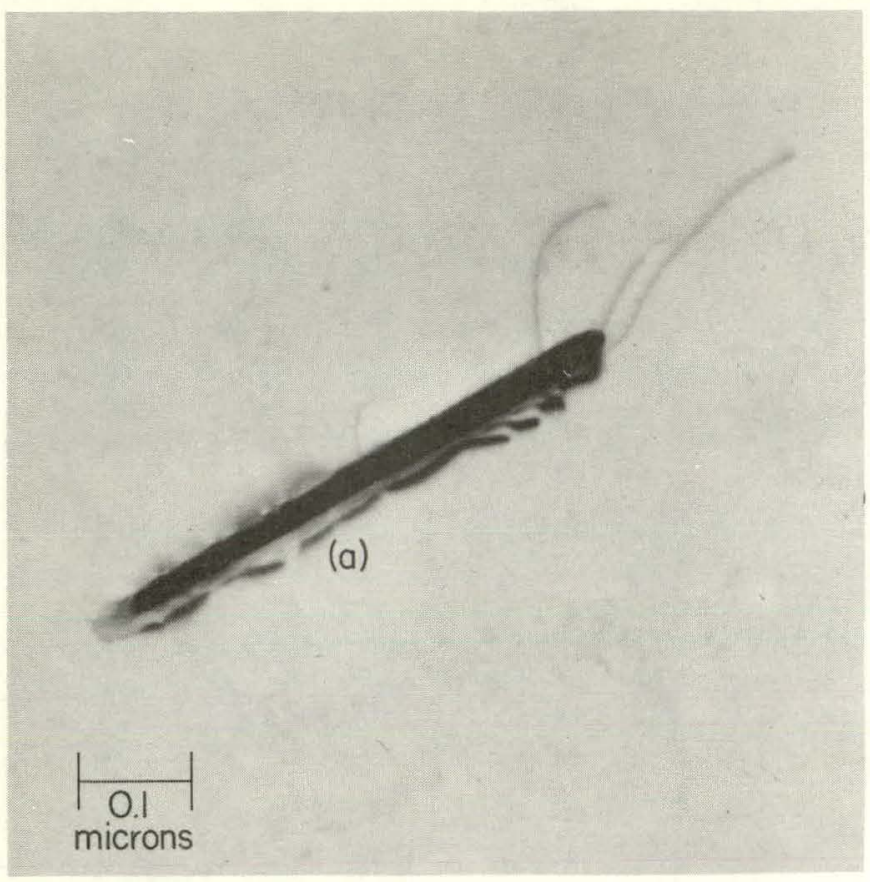

FIGURE 29. Higher magnification view of a single $\mathrm{FeBe}_{11}$ platelet in Figure 28 showing the associated dislocations and a small amount of strain contrast at the platelet face (a).

FIGURE 31. Precipitates $\left(\mathrm{FeBe}_{11}\right)$ in the matrix of a beryllium specimen quenched from $900^{\circ} \mathrm{C}$ and aged at $780^{\circ} \mathrm{C}$ for one hour.

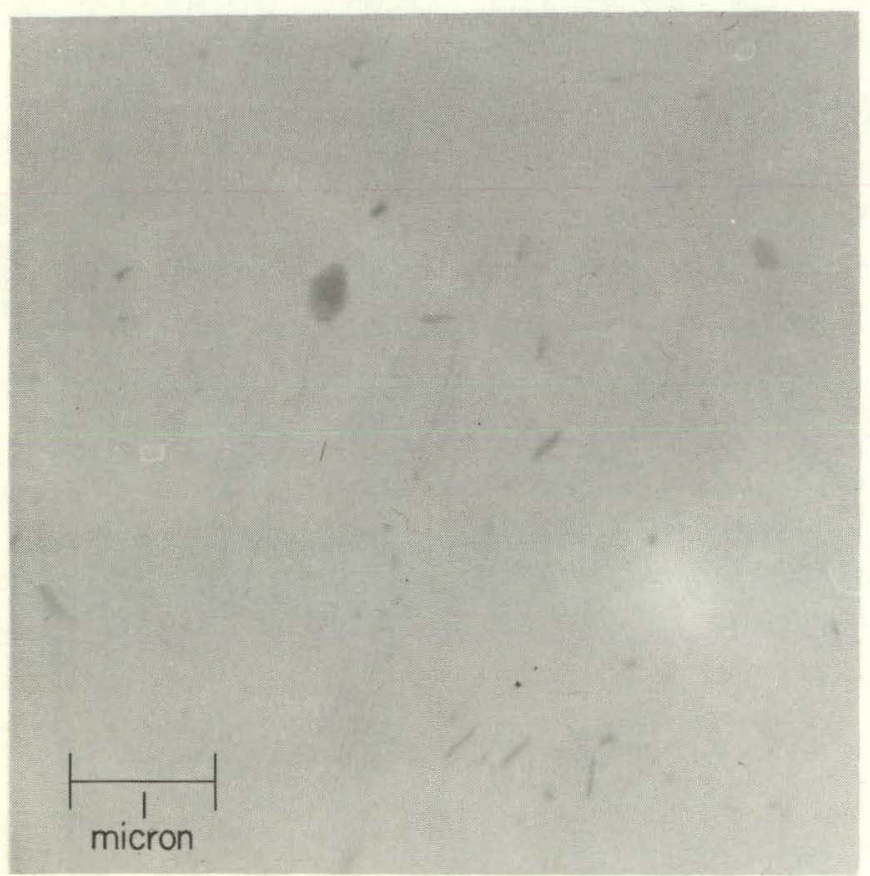

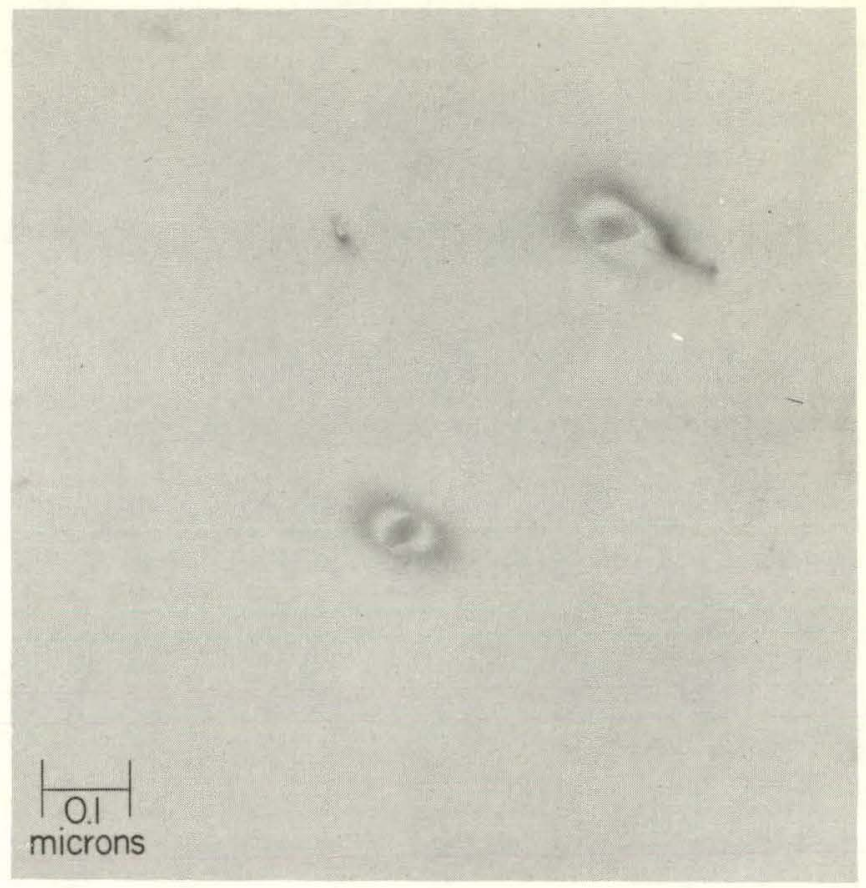

FIGURE 30. Strain contrast around two precipitate particles, approximately 500 angstroms in length, in a brine-quenched specimen; quenching temperature, $1000^{\circ} \mathrm{C}$ and annealing temperature, $780^{\circ} \mathrm{C}$ for one hour.

FIGURE 32. Precipitate plates $\left(\mathrm{FeBe}_{11}\right)$ in beryllium brine-quenched from $1200^{\circ} \mathrm{C}$ and aged at $780^{\circ} \mathrm{C}$ for one hour. The white spots are etch pits in the thin foil.

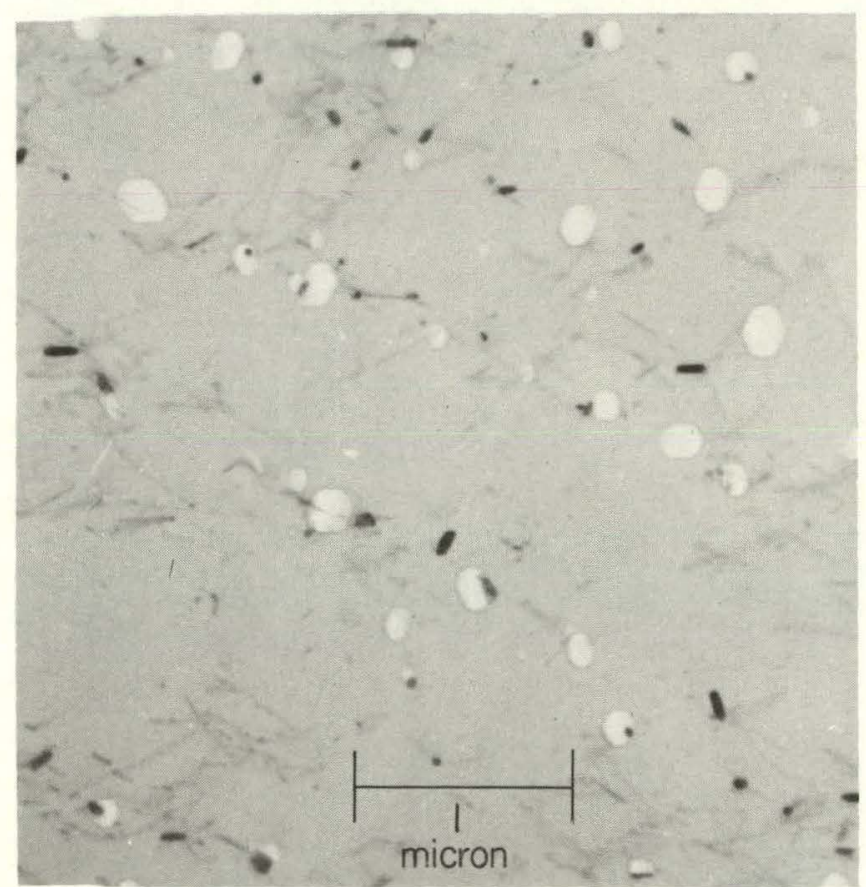




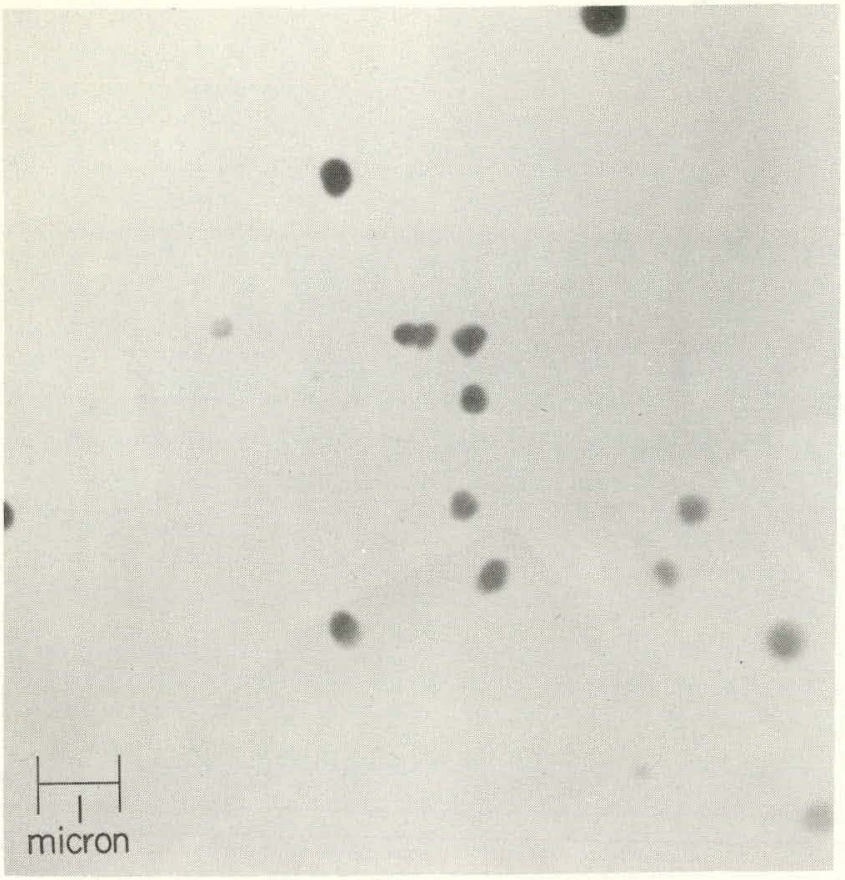

FIGURE 33. Globular precipitates, presumably $\mathrm{AlMBe}_{4}$, in the matrix of beryllium quenched in brine from $780^{\circ} \mathrm{C}$ and aged for one hour at $780^{\circ} \mathrm{C}$.

FIGURE 35. Higher magnification photomicrograph of the row of precipitates shown in Figure 34. Some of the precipitates appear to be plate-shaped (arrows).

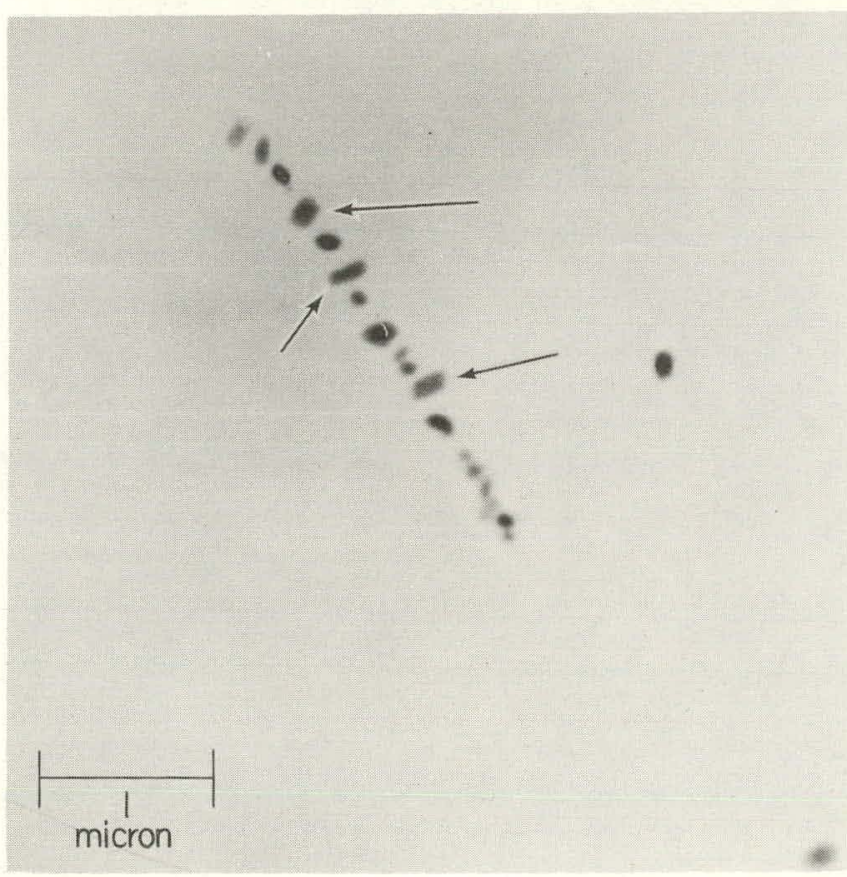

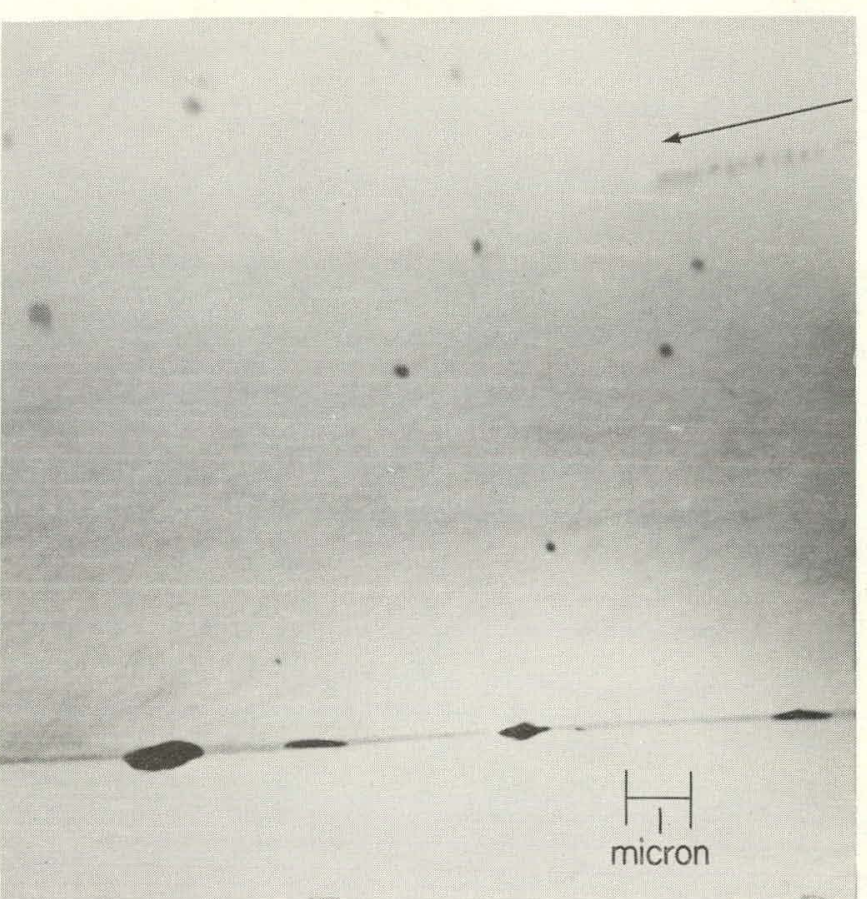

FIGURE 34. Grain-boundary and matrix precipitates in a beryllium ingot sheet sample, furnace-cooled from $1000^{\circ} \mathrm{C}$ to $225^{\circ} \mathrm{C}$ and then aged at $780^{\circ} \mathrm{C}$ for one hour. Note the row of precipitates along the arrow.

FIGURE 36. The $\mathrm{AlMBe}_{4}$ precipitates (probably $\mathrm{AlFeBe}_{4}$ ) in the matrix of a beryllium sample, furnace-cooled $\left(44^{\circ} \mathrm{C}\right.$ per minute) from $1000^{\circ} \mathrm{C}$ to $780^{\circ} \mathrm{C}$ and held at $780^{\circ} \mathrm{C}$ for one hour.

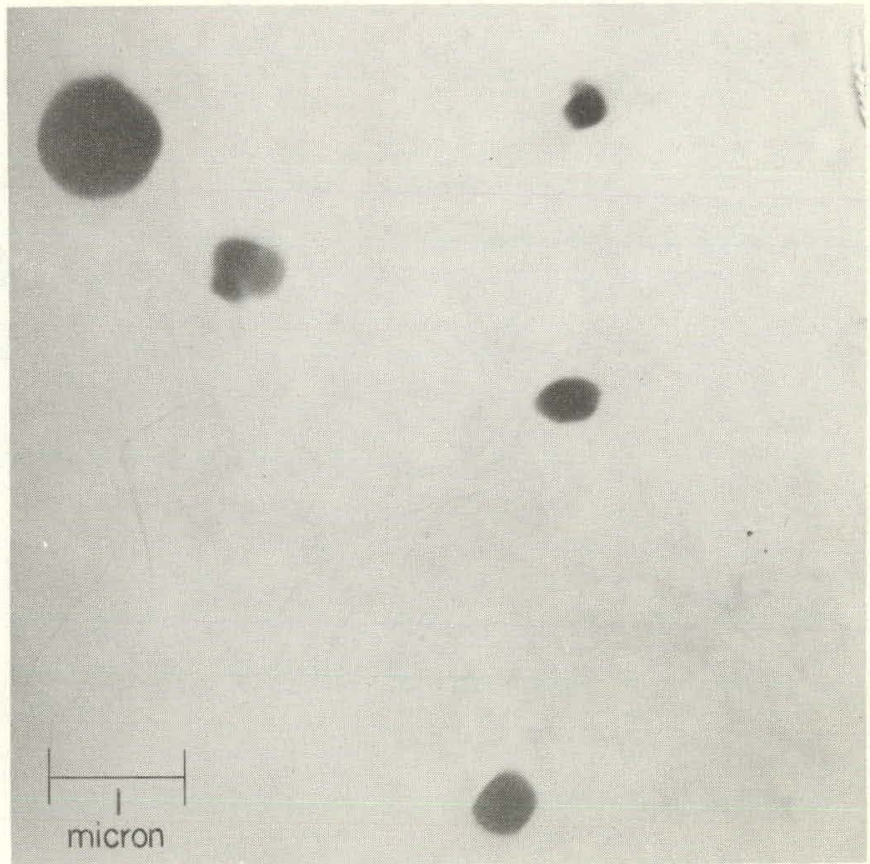




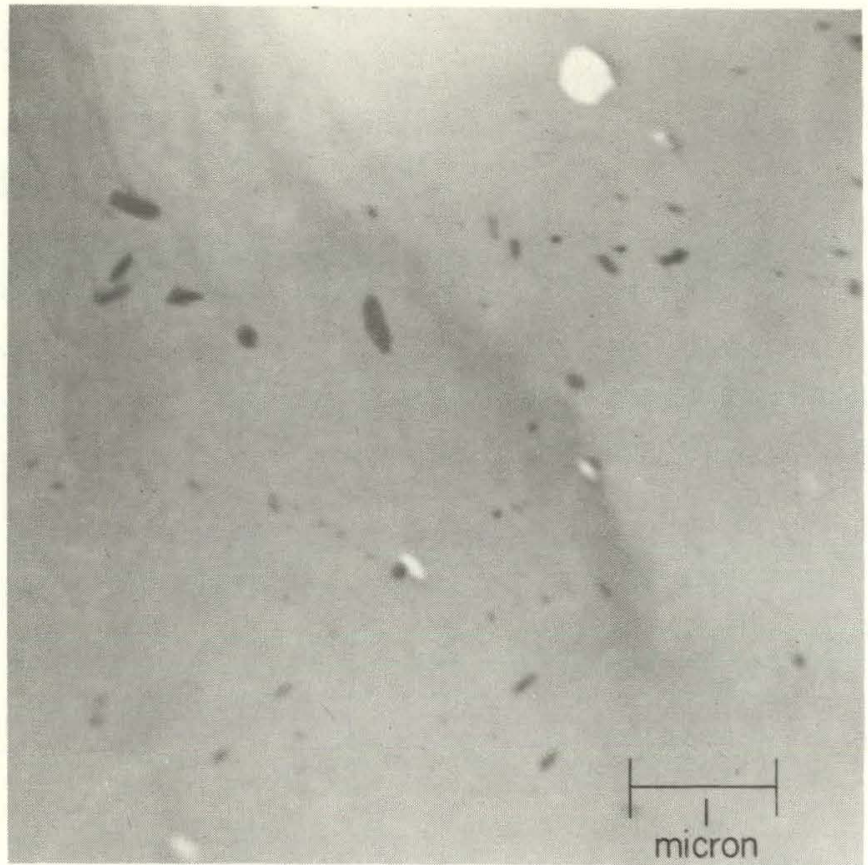

FIGURE 37. Matrix precipitates in beryllium-argon atmosphere cooled in the end of the furnace tube from $1000^{\circ} \mathrm{C}$ to $780^{\circ} \mathrm{C}$ and held at $780^{\circ} \mathrm{C}$ for one hour.

FIGURE 39. Small precipitates in beryllium ingot sheet brine-quenched from $1000^{\circ} \mathrm{C}$ and aged at $650^{\circ} \mathrm{C}$ for one hour.

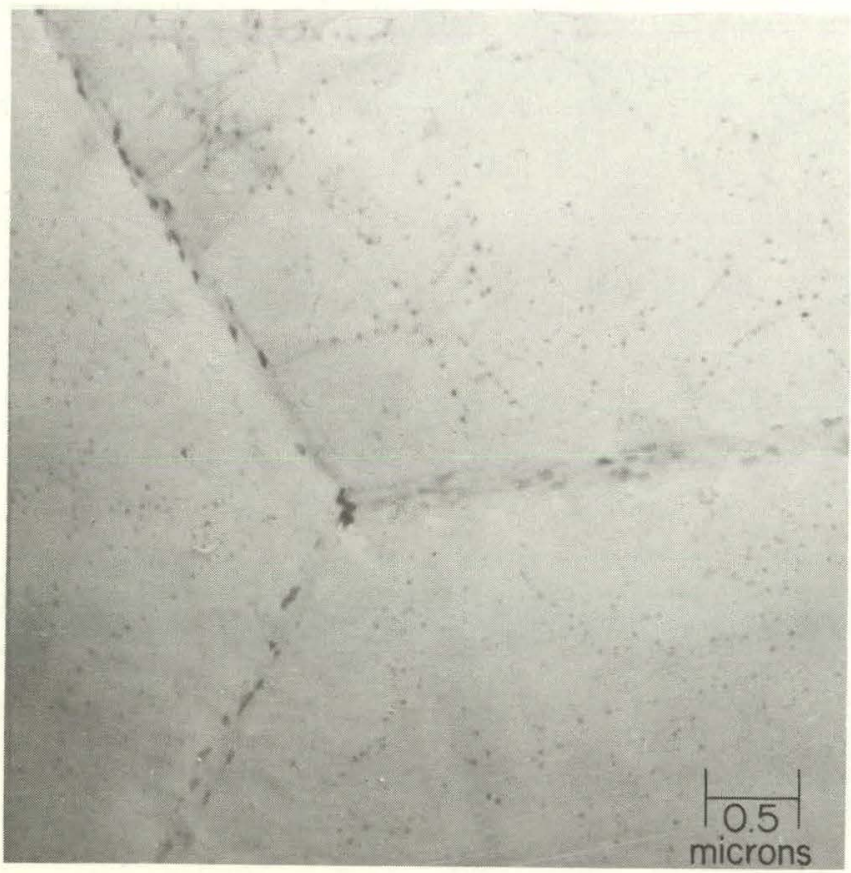

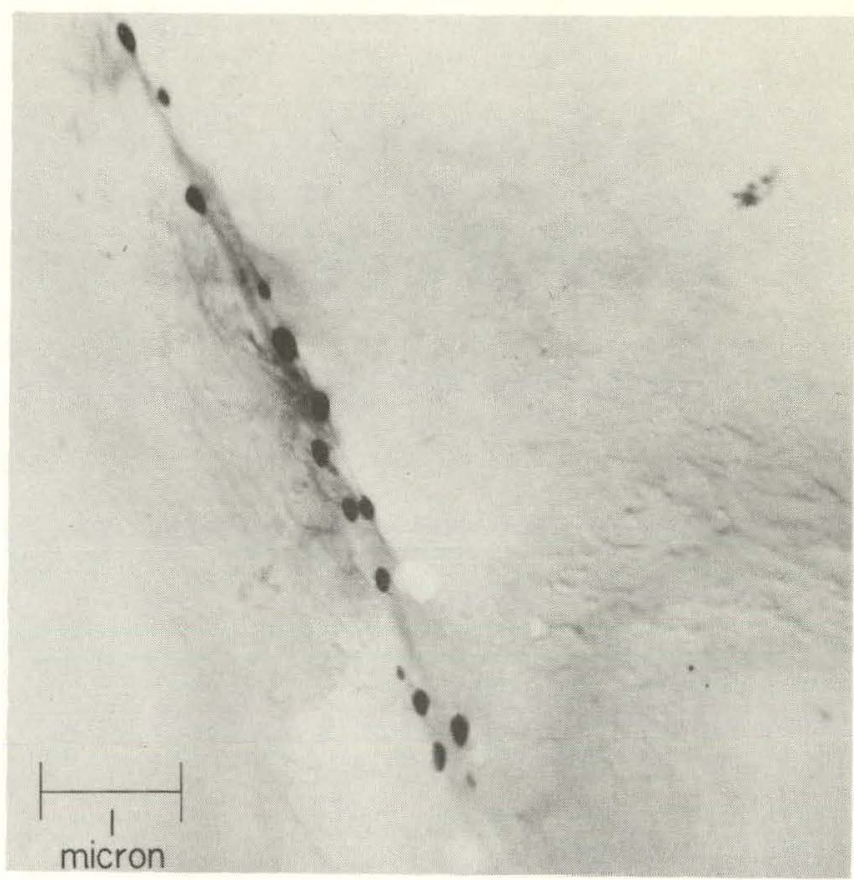

FIGURE 38. Grain-boundary precipitates in beryllium brine-quenched from $1000^{\circ} \mathrm{C}$ and aged for one hour at $850^{\circ} \mathrm{C}$.

FIGURE 40. Beryllium ing ot sheet quenched in brine from $1000^{\circ} \mathrm{C}$ and aged at $500^{\circ} \mathrm{C}$ for one hour. Little matrix precipitation.

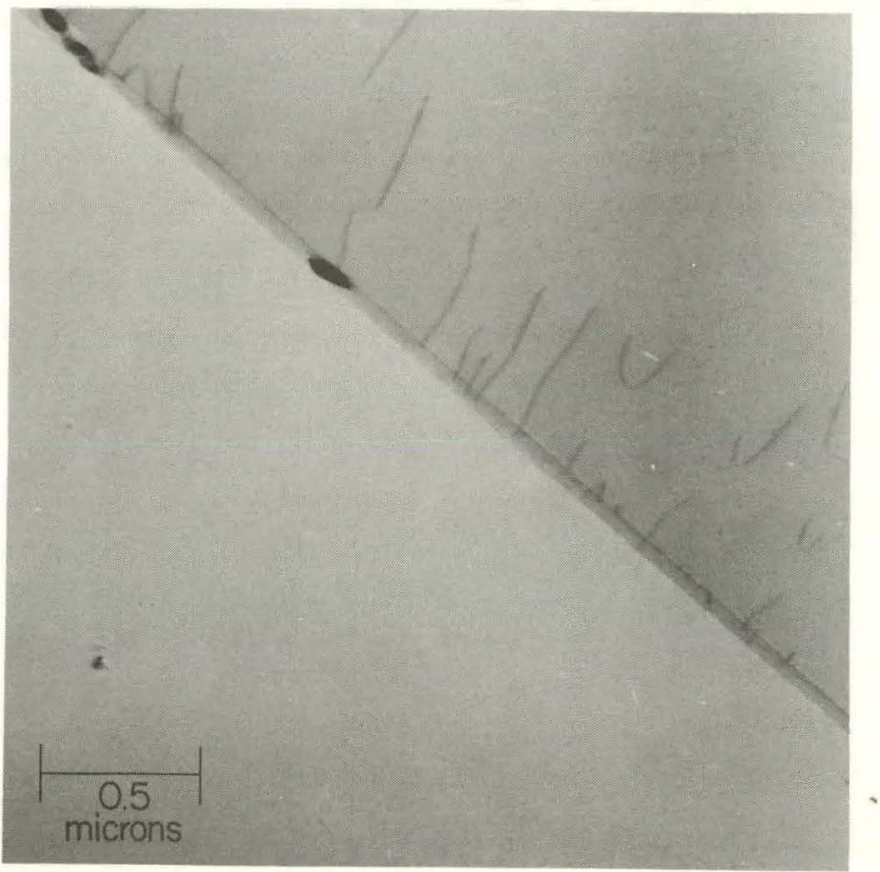




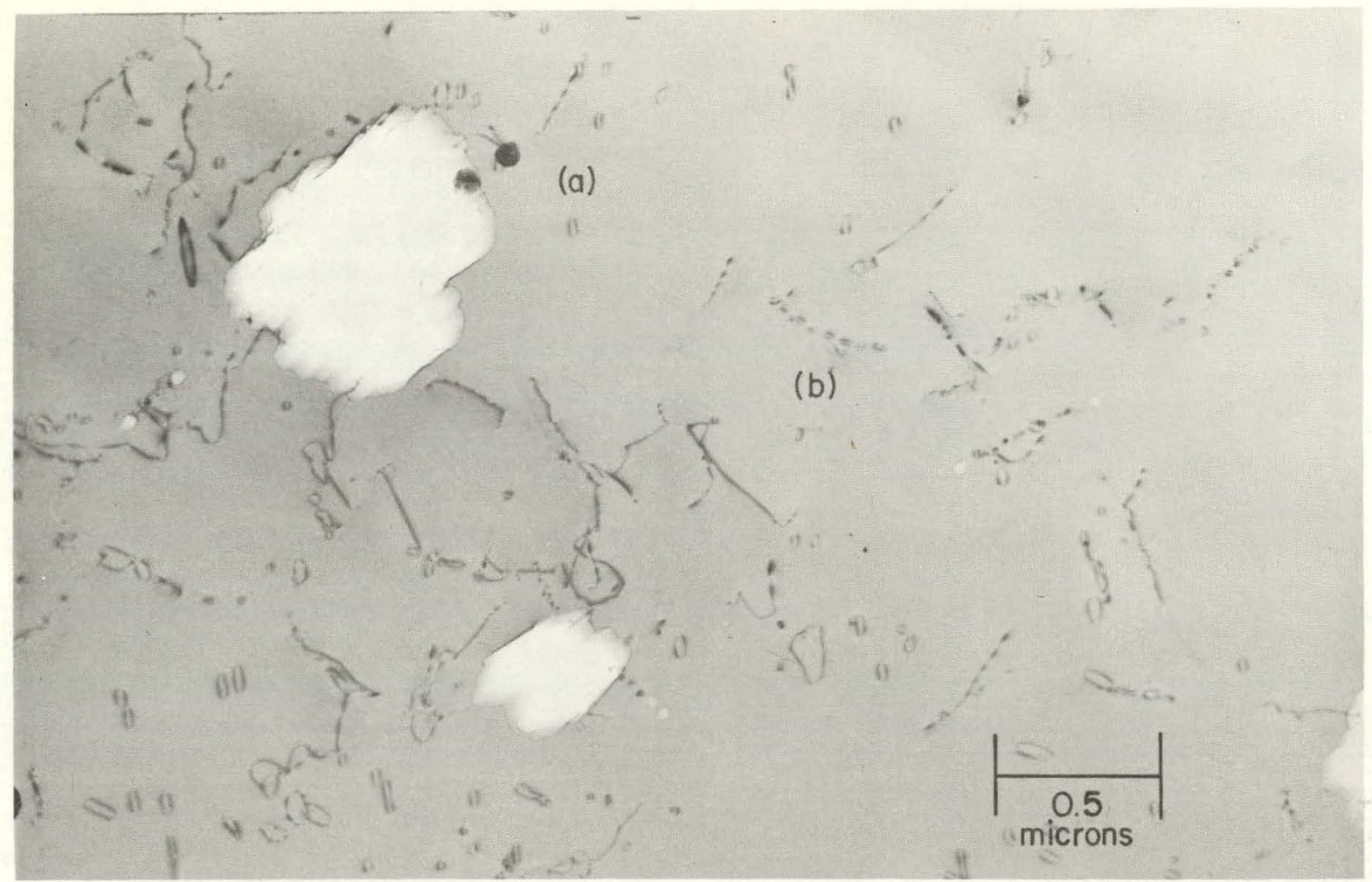

FIGURE 41. Beryllium foil tilted to show prismatic $(1 / 3<11 \overline{2} 0\rangle)$ dislocation loops and two small precipitate particles at (a); quenching temperature, $1000^{\circ} \mathrm{C}$ (brine-quench) and annealing temperature, $500^{\circ} \mathrm{C}$ for one hour. Note the row of dislocation loops at (b). The white spots are etch pits in the foil.

FIGURE 42. A small precipitate (arrow) which has remained in the grain boundary of a brine-quenched and aged sample reheated to $1000^{\circ} \mathrm{C}$. Quenching temperature, $1000^{\circ} \mathrm{C}$; annealing temperature, $780^{\circ} \mathrm{C}$ for one hour; and resolutionizing temperature, $1000^{\circ} \mathrm{C}$ for one hour. Note the absence of $\mathrm{FeBe}_{11}$ plates in the matrix.

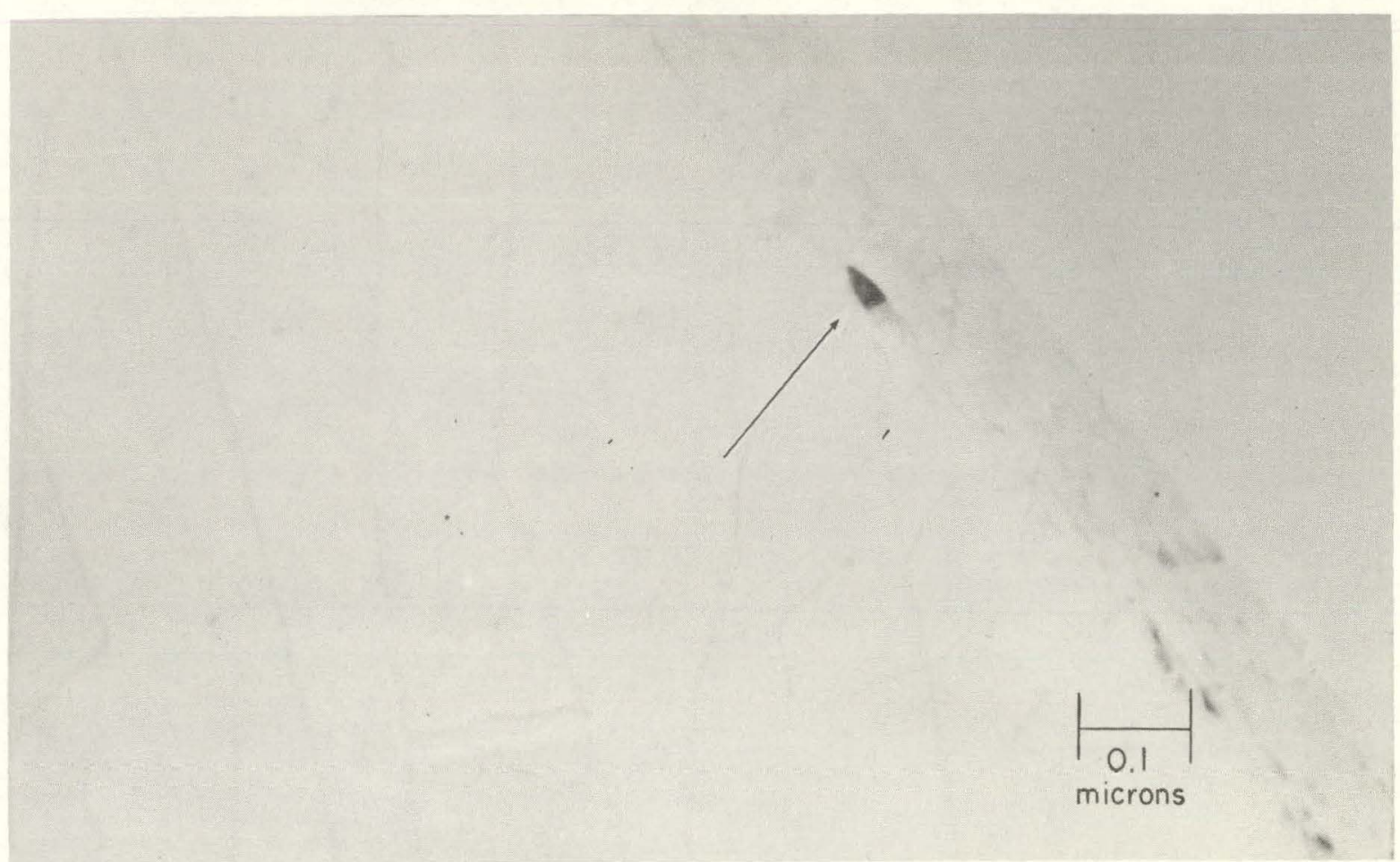




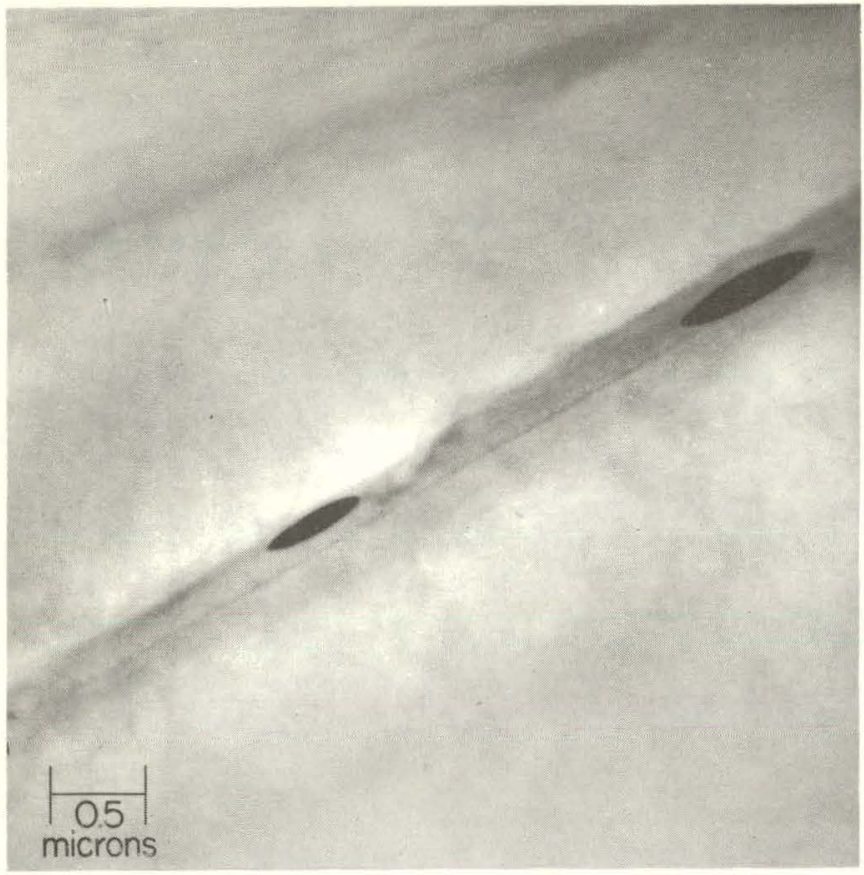

FIGURE 43. Lenticular, aluminum-rich precipitates in the grain boundary of beryllium ingot sheet brinequenched from $900^{\circ} \mathrm{C}$, aged for one hour at $780^{\circ} \mathrm{C}$ and resolutionized at $900^{\circ} \mathrm{C}$ for one hour.

FIGURE 45. Grain-boundary precipitate in beryllium furnace-cooled to room temperature and resolutionized at $1000^{\circ} \mathrm{C}$ for a quarter hour.

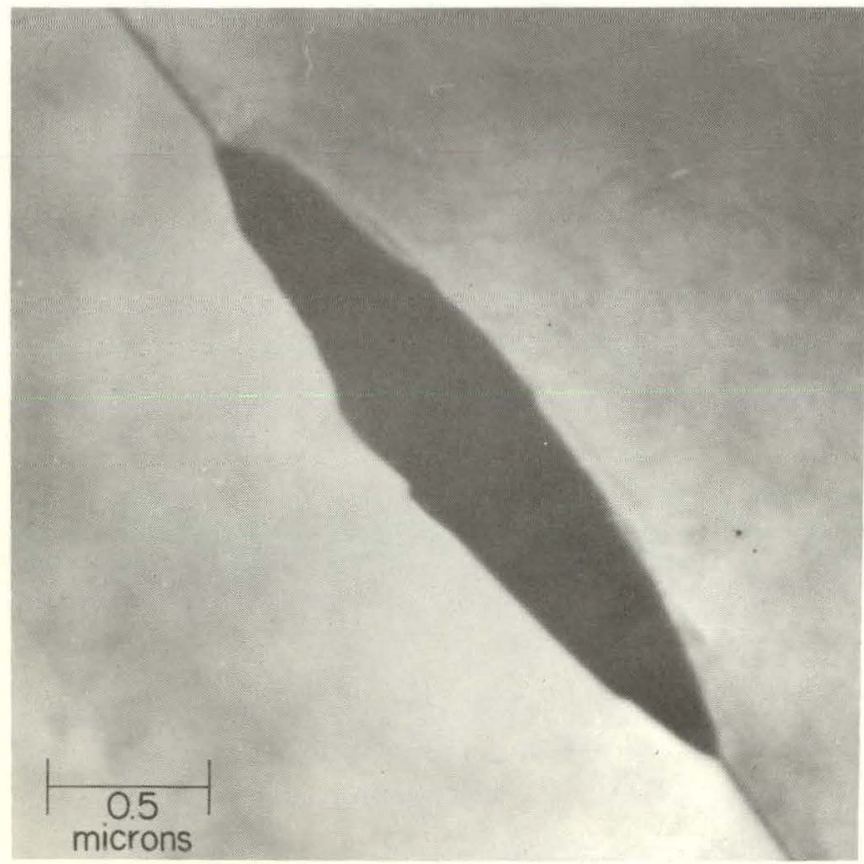

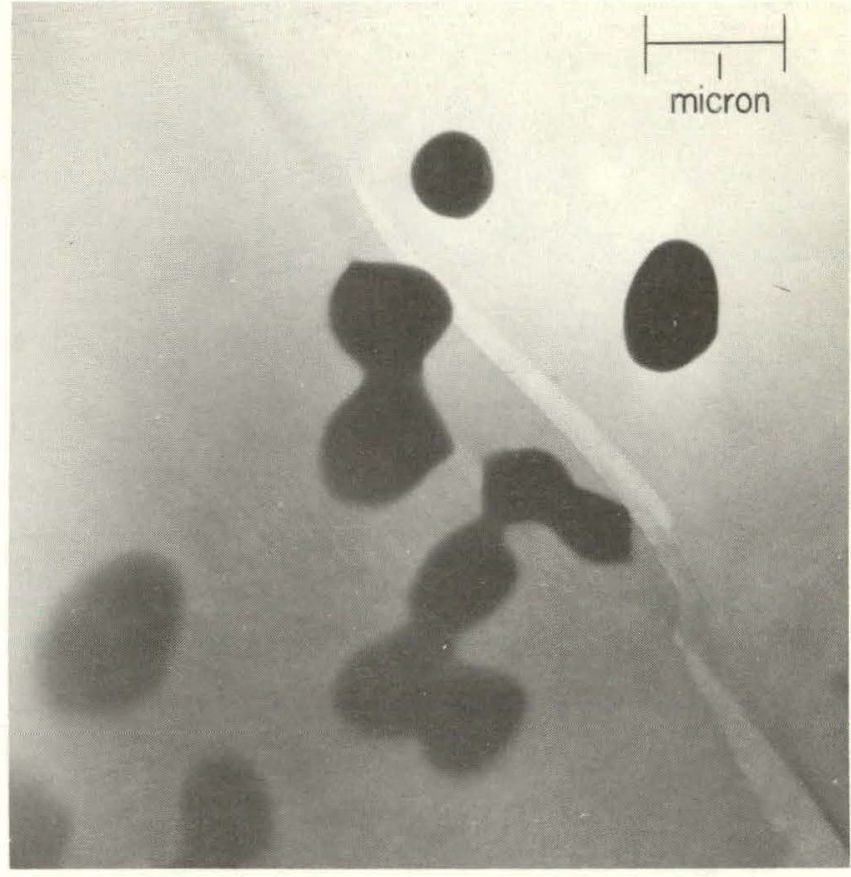

FIGURE 44. Precipitates $\left(\mathrm{AlFeBe}_{4}\right)$ in the matrix of a sample quenched from $850^{\circ} \mathrm{C}$, aged at $780^{\circ} \mathrm{C}$ for one hour and reheated at $850^{\circ} \mathrm{C}$ for one hour. The particles appear to be coalescing into precipitates of more than one micron in length.

FIGURE 46. Optical photomicrograph of beryllium ingot sheet quenched from $1100^{\circ} \mathrm{C}$ and aged at $780^{\circ} \mathrm{C}$ for one hour. The aluminum-rich inclusions are shown at the region marked by the arrow. The feature at (a) shows the etched remains of a Knoop microhardness indentation (magnification $300 \mathrm{X}$ ).

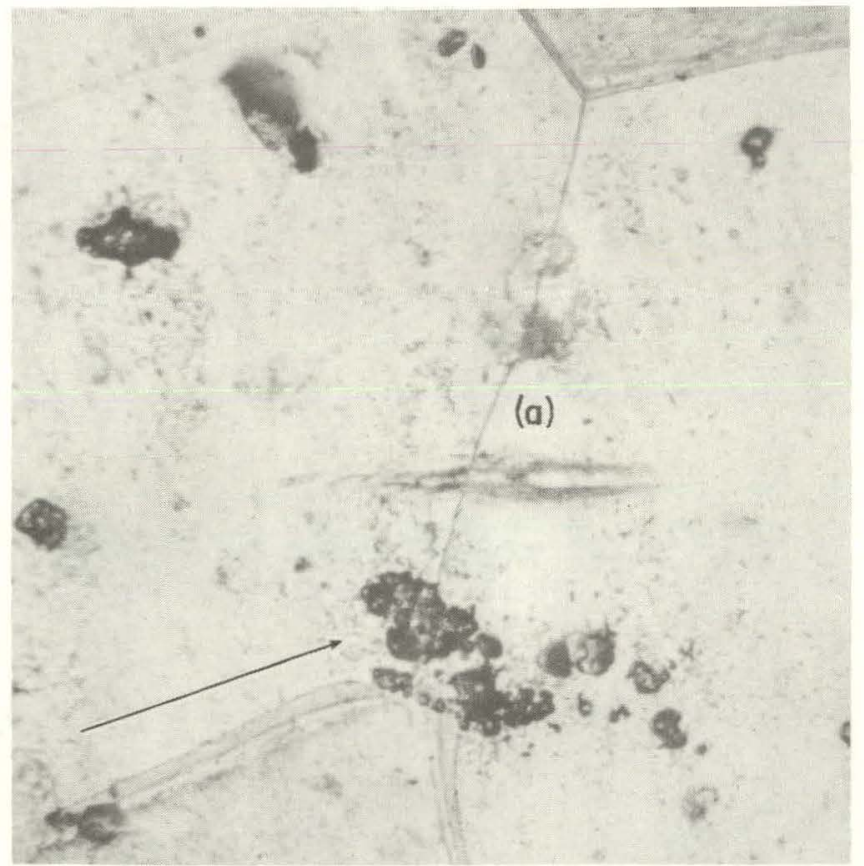




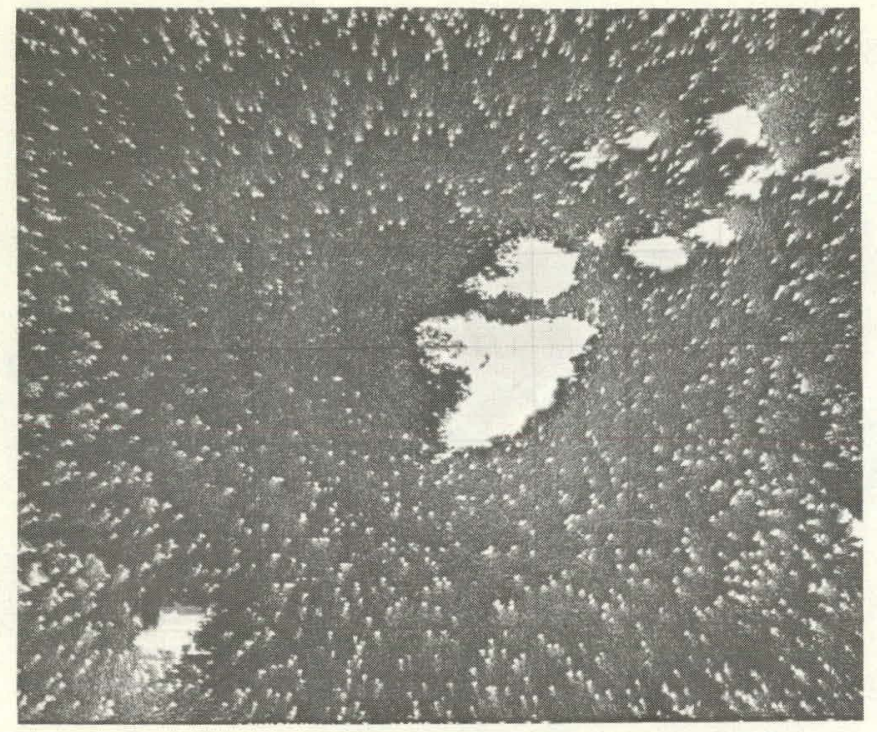

FIGURE 47. The aluminum- $\mathrm{K}_{\alpha}$ microprobe raster scan of the area in Figure 46. The aluminum count is 100,060 counts per 60 seconds in the inclusion area as compared to 117 counts per 60 seconds background and 293,235 from an aluminum standard. (Magnification 300X).

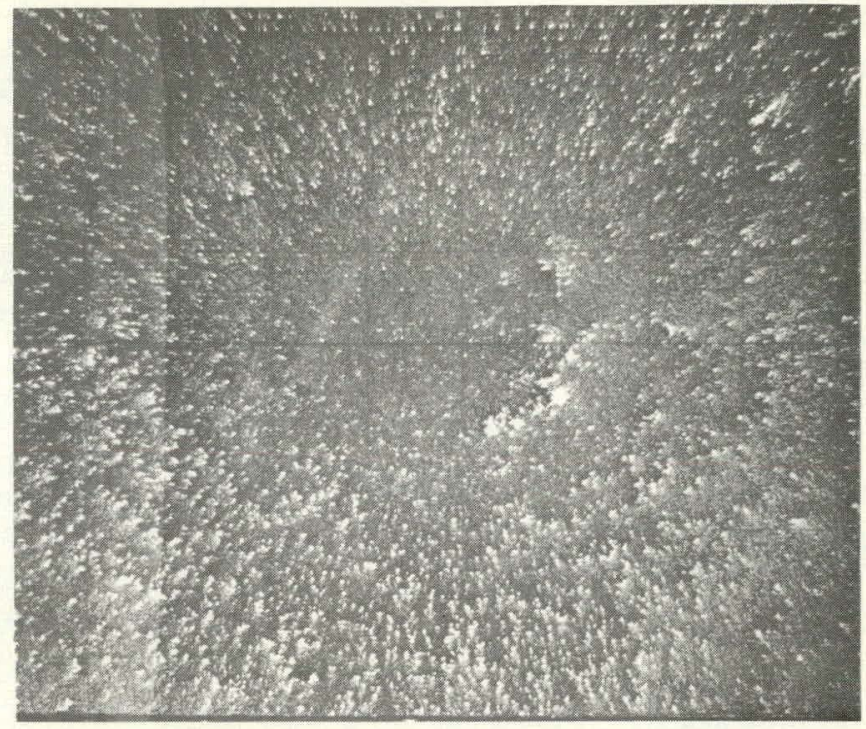

FIGURE 48. The iron- $\mathrm{K}_{\alpha}$ raster scan of the area in Figure 46. These raster scans are mirror images of Figure 46.

FIGURE 49. Sketch of the interaction of a screw dislocation with a row of prismatic loops shown in sequence (a), (b), and (c) to form a helical dislocation.

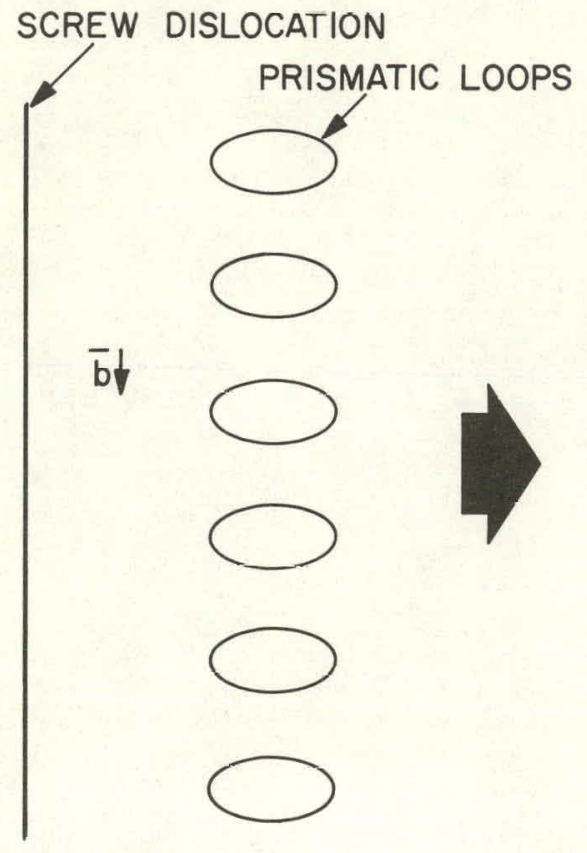

(a)

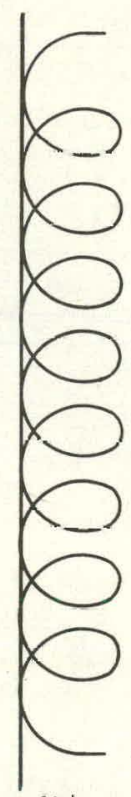

(b)

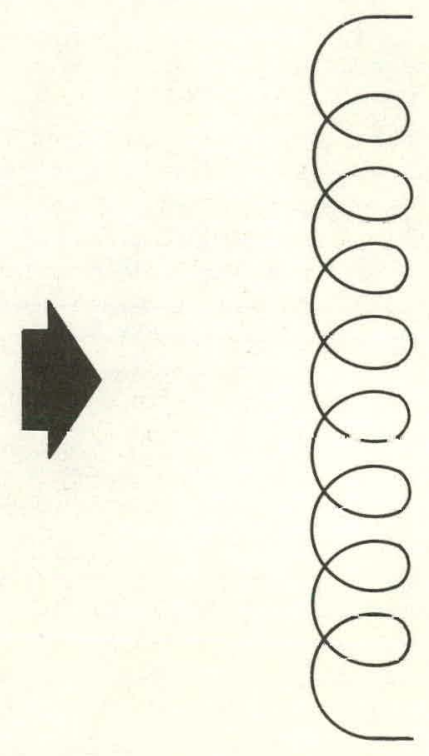

(c) 